WIDER Working Paper 2021/28

\title{
A manufacturing renaissance? Industrialization trends in the developing world
}

Hagen Kruse, ${ }^{1}$ Emmanuel Mensah, ${ }^{1}$ Kunal Sen, ${ }^{2}$ and Gaaitzen de Vries ${ }^{1 *}$

February 2021 
Abstract: This paper examines industrialization trends in developing countries. It uses the GGDC/UNU-WIDER Economic Transformation Database, which provides time series of employment and real and nominal value added annually by 12 sectors in 51 countries for the period 1990-2018. Until the early 2000s de-industrialization was widespread, but then the trend reversed. Regressions that control for income and demographic trends suggest significant employment industrialization in developing Asia and sub-Saharan Africa. We explore the nature of this manufacturing renaissance.

Key words: industrialization, Economic Transformation Database, manufacturing renaissance

JEL classification: N10; O14

Acknowledgements: We would like to thank Johannes van Biesebroeck, Joseph Kaboski, Marti Mestieri, Margaret McMillan, Andy Sumner, and participants in the UNU-WIDER seminar (October 2020) and STEG conference (January 2021) for stimulating comments and suggestions. The research on which this paper is based is part of the 'ETD - Economic Transformation Database' project, supported by UNU-WIDER.

Database: The GGDC/UNU-WIDER Economic Transformation Database (ETD) is accessible here (https://www.wider.unu.edu/database/etd- $\% \mathrm{E} 2 \% 80 \% 93$-economictransformation-database).

\footnotetext{
${ }^{1}$ Groningen Growth and Development Centre, University of Groningen, Groningen, the Netherlands; ${ }^{2}$ UNU-WIDER, Helsinki, Finland, and University of Manchester, Manchester, United Kingdom; * corresponding author: Gaaitzen de Vries, g.j.de.vries@rug.nl
}

This study has been prepared within the UNU-WIDER project ETD - Economic Transformation Database.

Copyright (C) UNU-WIDER 2021

UNU-WIDER employs a fair use policy for reasonable reproduction of UNU-WIDER copyrighted content-such as the reproduction of a table or a figure, and/or text not exceeding 400 words-with due acknowledgement of the original source, without requiring explicit permission from the copyright holder.

Information and requests: publications@wider.unu.edu

ISSN 1798-7237 ISBN 978-92-9256-966-2

https://doi.org/10.35188/UNU-WIDER/2021/966-2

Typescript prepared by Joseph Laredo.

United Nations University World Institute for Development Economics Research provides economic analysis and policy advice with the aim of promoting sustainable and equitable development. The Institute began operations in 1985 in Helsinki, Finland, as the first research and training centre of the United Nations University. Today it is a unique blend of think tank, research institute, and UN agency — providing a range of services from policy advice to governments as well as freely available original research.

The Institute is funded through income from an endowment fund with additional contributions to its work programme from Finland, Sweden, and the United Kingdom as well as earmarked contributions for specific projects from a variety of donors.

Katajanokanlaituri 6 B, 00160 Helsinki, Finland

The views expressed in this paper are those of the author(s), and do not necessarily reflect the views of the Institute or the United Nations University, nor the programme/project donors. 
Historically, the reallocation of workers from low-productive traditional to high-productive modern activities has driven sustained improvements in living standards. The industrial revolution initiated a long period of economic and productivity growth in Europe and the United States (Mokyr 1990). Industrialization has also been central to the success stories of Asian countries, catching up and converging to income levels observed in the West (Szirmai and Verspagen 2015). Indeed, dynamic modern sectors that absorb workers appear crucial for development and poverty reduction.

However, scholars have documented de-industrialization trends in much of the developing world in recent decades (e.g. Atolia et al. 2020; Felipe et al. 2014; Haraguchi et al. 2017; Palma 2005; Rodrik 2016). That finding is worrying. It suggests that the traditional route to development has become more difficult. Yet, other scholars have argued-especially in the context of Africa-that it is too soon to conclude that countries are running out of industrialization opportunities (Diao et al. 2017; Haraguchi et al. 2017; Mensah 2020; Nguimkeu and Zeufack 2019).

This paper analyses industrialization trends for a large set of developing countries. It studies the dynamics of manufacturing output and employment based on the new GGDC/UNU-WIDER Economic Transformation Database (ETD). We make three contributions. First, the introduction of the ETD itself, which provides consistent time series of employment and real and nominal value added (VA) by 12 sectors in 51 countries, annually for the period from 1990 to 2018. It covers 20 Asian, 9 Latin American, 4 Middle-Eastern and North African (MENA), and 18 sub-Saharan African economies at varying levels of economic development. The ETD has been constructed from an in-depth investigation of the availability and usability of statistical sources on a countryby-country basis.

The second contribution is to use manufacturing data to examine industrialization trends in the developing world. We confirm that de-industrialization was widespread until the early 2000 s, but the trend reversed thereafter. We document an expansion of the manufacturing employment share for many countries in Asia and sub-Saharan Africa. In developing Asia, the average manufacturing employment share increased from 11.9 per cent in 2010 to 13.4 per cent by 2018. In sub-Saharan Africa, the share of workers in manufacturing rose by 1.2 percentage points to 8.4 per cent during the period 2010-18. Although the level of manufacturing activity in sub-Saharan Africa is low in comparison with that in other regions, as well as from a historical perspective, ${ }^{1}$ the increase is an important reversal to a long-run de-industrialization trend that was documented for the period from 1960 to 2010 (Felipe et al. 2014; Rodrik 2016). We confirm the statistical significance of these trends in regressions similar to those used by Rodrik (2016), where we control for country-fixed effects and demographic and income trends. For sub-Saharan Africa, the regression estimates suggest a recovery of manufacturing by more than half the downward shift observed during the period 1960-2010.

A third contribution is to explore the nature of the manufacturing renaissance. We ask whether industrialization relates to an expansion of jobs at firms that meet the minimum size or registration criteria to be included in official industrial surveys. For developing Asia we find, on average, that industrialization does not appear to be predominantly driven by jobs in registered or unregistered

\footnotetext{
${ }^{1}$ At its peak in the 1960s and 1970s, manufacturing employed about one quarter to one third of the labour force in France, Germany, Sweden, and the United Kingdom (see figure 5 in Rodrik 2016).
} 
firms. It likely differs according to the developing Asian country considered. However, for subSaharan Africa our findings suggest an absorption of workers by unregistered small manufacturing firms. We further distinguish between those countries that are manufactures exporters and those that are non-manufactures exporters and find that domestic rather than foreign demand appears related to industrialization. This suggests that small-scale firms in sub-Saharan African have increased production of (low-) quality goods to meet rising demand by domestic consumers.

As Lewis (1979) noted, such an expansion of small-scale activity in manufacturing is an important part of the development process. Indeed, small firms may meet domestic demand and provide employment in the process. Do these firms use traditional technologies with limited opportunities for productivity growth? If so, the manufacturing renaissance in Africa is unlikely to drive sustained development. Yet, if these firms use modern technologies, the expansion of small-scale activities is in fact an important part of the development process. In fact, both traditional and modern techniques are observed across unregistered firms (Danquah et al. 2019; Diao and McMillan 2018), and we speculate that the expansion of markets provides a steppingstone for small-scale modern activity in Africa.

This paper is closely related to the large literature on industrialization and development, whose focus is on employment industrialization, because the expansion of manufacturing jobs is a strong predictor of higher levels of economic development (Felipe et al. 2014). Various scholars have argued that countries run out of industrialization opportunities at lower levels of income and at manufacturing employment shares below those experienced by earlier industrializers (Atolia et al. 2020; Felipe et al. 2014; Palma 2005; Rodrik 2016). However, Mensah (2020) argues that industrialization trends in sub-Saharan Africa are sensitive to the size of the sample of countries considered. Our findings suggest that for many developing countries the employment share in manufacturing may not yet have peaked. When we use the same set of countries as in Rodrik (2016), we do not find industrialization, but the larger sample of African countries in the ETD indicates a significant industrialization trend. This suggests that the de-industrialization trend in sub-Saharan Africa is indeed sensitive to the set of countries considered.

It also suggests cross-country diversity in industrialization trends. Differential patterns of manufacturing output and employment shares have been documented across Asia by Sen (2019), and in Africa by Nguimkeu and Zeufack (2019) and Mensah (2020). We contribute to these studies by analysing country-specific industrialization patterns.

Finally, we relate to the literature that examines the characteristics of industrialization. Lewis (1979) argued that the expansion of modern activities, often initially at a small scale, is a necessary development phase. Diao et al. (2021) study the size and characteristics of manufacturing firms in Ethiopia and Tanzania. They find that the bulk of employment growth is concentrated in enterprises not covered in official surveys. ${ }^{2}$ We find evidence of this in a wider set of countries in Africa.

The remainder of the paper is structured as follows. Section 2 presents the content and main characteristics of the ETD. Section 3 documents trends in the output and employment share of manufacturing across the developing world. Section 4 describes the regression specifications that are used in Section 5 to examine the significance of industrialization time trends conditional on demographic and income trends. Section 6 examines how findings are affected by the sample of

\footnotetext{
${ }^{2}$ See also The Economist (2020).
} 
countries considered and compares industrialization patterns specific to individual countries. Section 7 explores the nature of industrialization. Section 8 provides concluding remarks.

\section{Data}

Subsection 2.1 presents the GGDC/UNU-WIDER Economic Transformation Database (ETD). Subsection 2.2 discusses the 2-digit manufacturing dataset, which is used in some of the extensions of the analysis, and income and population data from the Maddison 2020 release (Bolt and van Zanden 2020; Maddison 2020).

\subsection{The Economic Transformation Database}

The ETD is the successor to the GGDC 10-sector database (10SD). It is not an update of time series in an existing sectoral dataset, but a new dataset built using primary data sources. In contrast to the 10SD, the ETD has better coverage of low-income developing countries, distinguishes 12 sectors in the International Standard Industrial Classification revision 4 (ISIC rev. 4), and has time series that run until 2018.

This subsection discusses the content of the ETD, the guiding philosophy to ensure that it meets the requirements of consistency necessary for growth and productivity analysis, and the ETD's relation to other publicly available datasets.

Table 1 gives an overview of the content of the ETD. The dataset consists of 51 countries at varying levels of economic development: 20 Asian, 9 Latin American, 4 Middle-Eastern and North African (MENA), and 18 sub-Saharan African economies. According to data for 2018, they account for a major part of the output of each region, namely 98 per cent, 82 per cent, 36 per cent, and 73 per cent of GDP in Asia, Latin America, MENA, and sub-Saharan Africa, respectively. ${ }^{3}$ The ETD countries account for 55 per cent of global real manufacturing VA and 42 per cent of global GDP. ${ }^{4}$ The database is constructed by an in-depth investigation of the availability and usability of statistical sources on a country-by-country basis. See de Vries et al. (2021) for a detailed documentation of the sources and methods.

The ETD includes annual data on gross VA at both real and nominal prices for the period 1990 2018. Data on persons employed is also included such that trends in labour productivity (VA per worker) can be derived. The database covers the 12 main sectors of the economy as defined in ISIC rev. 4. Together these 12 sectors cover the total economy.

Gross VA in real and nominal prices is from the National Accounts (NA) published by the National Statistical Institutes (NSIs). VA by sector is compiled according to the UN System of National Accounts (SNA). This system accounts for income from both formal and informal activities. In addition, international comparability is high, in principle. However, NSIs frequently change their methodologies and conduct new surveys. The general approach is to start with GDP data for the most recent available benchmark years from the NA provided by the NSI or Central

\footnotetext{
${ }^{3}$ These numbers are based on VA at constant 2015 prices in US dollars for the year 2018, as reported by the UN National Accounts database. As a share of VA in manufacturing the dataset accounts for 99 per cent, 79 per cent, 50 per cent, and 74 per cent in Asia, Latin America, MENA, and sub-Saharan Africa, respectively. Note that Russia is not included in Asia.

${ }^{4}$ Comparable data for North American and European countries is available at www.euklems.eu.
} 
Bank. These data are typically compiled according to the 2008 SNA (UN 2008), but methods of compilation vary by country, as some countries still follow the approaches outlined in the 1993 SNA (UN 1993). Historical NA series are subsequently linked to the benchmark year data. The linking procedure ensures that growth rates of individual series are retained while absolute levels are adjusted according to the most recent information and methods.

Table 1: Content of the GGDC/UNU-WIDER Economic Transformation Database

\begin{tabular}{|c|c|}
\hline \multicolumn{2}{|l|}{ Countries included: } \\
\hline Developing Asia (14) & $\begin{array}{l}\text { Bangladesh, Cambodia, China, India, Indonesia, Lao People's } \\
\text { Democratic Republic, Malaysia, Myanmar, Nepal, Pakistan, Philippines, } \\
\text { Sri Lanka, Thailand, Viet Nam }\end{array}$ \\
\hline Advanced Asia (6) & $\begin{array}{l}\text { Chinese Taipei, Hong Kong (China), Israel, Japan, Korea (Rep. of), } \\
\text { Singapore }\end{array}$ \\
\hline Latin America (9) & $\begin{array}{l}\text { Argentina, Bolivia, Brazil, Chile, Colombia, Costa Rica, Ecuador, Mexico, } \\
\text { Peru }\end{array}$ \\
\hline Middle East and North Africa (4) & Egypt, Morocco, Tunisia, Turkey \\
\hline Sub-Saharan Africa (18) & $\begin{array}{l}\text { Botswana, Burkina Faso, Cameroon, Ethiopia, Ghana, Kenya, Lesotho, } \\
\text { Malawi, Mauritius, Mozambique, Namibia, Nigeria, Rwanda, Senegal, } \\
\text { South Africa, Tanzania, Uganda, Zambia }\end{array}$ \\
\hline ISIC rev. 4 sector & Brief description \\
\hline A & Agriculture \\
\hline B & Mining \\
\hline C & Manufacturing \\
\hline $\mathrm{D}+\mathrm{E}$ & Utilities \\
\hline $\mathrm{F}$ & Construction \\
\hline $\mathrm{G}+\mathrm{I}$ & Trade services \\
\hline $\mathrm{H}$ & Transport services \\
\hline $\mathrm{J}+\mathrm{M}+\mathrm{N}$ & Business services \\
\hline K & Financial services \\
\hline L & Real estate \\
\hline $\mathrm{O}+\mathrm{P}+\mathrm{Q}$ & Government services \\
\hline $\mathrm{R}+\mathrm{S}+\mathrm{T}+\mathrm{U}$ & Other services \\
\hline Time period & 1990-2018 (annual data) \\
\hline Variables & $\begin{array}{l}\text { Gross VA at constant (2015) prices (national currency in millions) } \\
\text { Gross VA at current prices (national currency in millions) } \\
\text { Persons employed (in thousands) }\end{array}$ \\
\hline Principal sources & $\begin{array}{l}\text { National accounts; population censuses; labour force surveys; } \\
\text { establishment surveys }\end{array}$ \\
\hline
\end{tabular}

Note: Asian countries are grouped into developing and advanced Asia based on the classification by the IMF (2020).

Source: authors' illustration from www.GGDC.net and www.wider.unu.edu.

Volume data are estimated separately from constructed series of nominal VA and price deflators. This has several advantages. In cases where price statistics are missing or inaccurate, price trends of the aggregate sector are representative of the underlying detailed sectors. It is more reasonable to make this assumption for price developments than for volume growth rates. In addition, this method allows information on price developments to be added from external sources, such as the consumer price index, when this is not available from primary sources.

The VA from real estate activities (ISIC rev. 4, industry L) consists of VA from rental activities and imputations of owner-occupied housing. The latter imputation is based on an equivalent rent approach and is added to GDP. Imputed income from dwellings does not have an employment 
equivalent and therefore is preferably excluded in productivity analyses. This is possible because real estate activities are separately reported in the ETD.

Employment in the ETD is defined as 'all persons engaged', thus including all paid employees, but also self-employed and family workers, aged 15 years and older. Hence, it aims to include both formal and informal workers. Ideally, labour input is measured in hours worked, as differences in hours worked across sectors affect sectoral productivity gaps (Gollin et al. 2014; McCullough 2017). However, the data, insofar as they are available, are irregular and information on hours worked typically covers only the formal sector.

Employment information is typically not available from a country's NA, as it is not part of the SNA. For most countries, population censuses are used as these ensure full coverage of the (formal and informal) working population and a reliable sectoral breakdown. However, population censuses are typically quinquennial or decennial and cannot be used to derive annual trends. Moreover, many developing countries had a census scheduled for 2019/2020, which could not be incorporated because of a lag in data dissemination. Several population censuses have also been postponed due to the Covid-19 pandemic.

Whenever appropriate, population censuses are used to indicate absolute levels of employment, and labour force surveys (LFS) and establishment surveys are used to indicate trends in between. For countries where population census data are not used, nationally representative LFS are used as benchmarks instead. If employment series are not available to measure trends between benchmarks, the interpolation between benchmarks is based on the ILO model-based sectoral employment trends or the average trends in labour productivity between benchmark years for nonagricultural sectors. Employment in agriculture is interpolated between benchmarks using series of the economically active population in agriculture (see de Vries et al. 2021 for further information).

The ETD aims to include recent sources of data on sectoral employment and rebased national accounts. This is deemed crucial to account for the rapid growth of small business activities, in particular in sub-Saharan Africa. Clearly, reliability issues such as those related to the quality and coverage of informal activities remain. Yet, the in-depth investigation of sources on a country-bycountry basis strives to provide the best estimates possible.

Here, we provide one specific example of how we arrived at manufacturing employment estimates for Ethiopia. ${ }^{5}$ To start with, source data on manufacturing employment in Ethiopia provide conflicting information on levels and trends. The trend in manufacturing employment between the 2005 and 2013 national LFS suggests an annual manufacturing employment growth rate of 2.7 per cent, which is lower than the population growth rate of 3.1 per cent and total employment growth rate of 3.8 per cent reported in the LFS for this period. It also conflicts with other sources, which indicate higher growth rates of manufacturing employment. For example, data from the small-scale industry surveys for 2006 and 2014 suggest an annual growth rate of 14.6 per cent. Data from the urban employment and unemployment surveys for 2010 and 2014 give an annual growth rate of 10.3 per cent, and the large and medium-scale manufacturing censuses for 2010 15 give an annual growth rate of 15.3 per cent. We follow the approach by Diao et al. (2021) to estimate recent levels and trends in manufacturing employment for Ethiopia. Namely, we combine manufacturing workers reported in the large and medium-scale manufacturing censuses (including

\footnotetext{
${ }^{5}$ We are grateful to Xinshen Diao and Maggie McMillan for discussions and data provision for Ethiopia and Tanzania. See de Vries et al. (2021) for a detailed discussion and exposition of the sources and methods for each country in the ETD.
} 
temporary workers), non-food manufacturing workers from the small-scale industry survey (excluding seasonal workers), and urban and rural food manufacturing workers reported in the living standards measurement study surveys.

Several alternative sectoral datasets are publicly available. The best known is the World Bank's World Development Indicators (WDI). Figures for VA in the WDI are based on national accounts data and are therefore comparable to those in the ETD. For employment, recent editions of the WDI use ILO model-based estimates. ${ }^{6}$

The measurement of sectoral employment in the ETD and the ILO model have several similarities, including the selection of available statistical sources to create inter-temporally consistent series, and the use of nationally representative data sources. Yet, whereas the ETD prefers population censuses, the ILO model prioritizes LFS. Sometimes LFS are not nationally representative and cover urban agglomerations only. ${ }^{7}$ It also matters when an LFS is conducted-during the dry or harvesting season. For example, the 2014 and 2018 LFS of Burkina Faso were conducted in the dry season. As a result, the employment share in agriculture drops from about 80 per cent in 2006 to around 30 per cent from 2014 onwards in the ILO model-based estimates. Such unreliable series are avoided in the ETD. Another major difference is the use of econometric imputation methods to fill blanks in the ILO model (see Klasen 2019 for a discussion).

Perhaps most importantly, at the $19^{\text {th }}$ International Conference of Labor Statisticians (ICLS) in 2013 it was decided to narrow the definition of the labour force to those that work for pay or profit (ICLS 2013). ${ }^{8}$ That revised definition of the labour force has a downward effect on the level of agricultural employment, because farmers that mainly or exclusively produce for own use are no longer included in employment by the ILO model-based estimates (Gaddis et al. 2020; Klasen 2019).

The revised definition of the labour force by the ILO is deeply problematic for several reasons (Klasen 2019). First, it will be difficult to obtain accurate and consistent time series of employment in developing countries where subsistence production is common. ${ }^{9}$ Second, it will result in breaks in the series. Third, it will create inconsistency between VA and employment. Production of agricultural goods for own use falls within the boundaries of the SNA and is therefore included in agricultural VA even if workers are not reported by the ILO. ${ }^{10}$ Labour productivity suddenly shoots up as output is measured, but workers are not measured. Fourth, it results in misleading information on the sectoral distribution of employment (Gaddis et al. 2020). Subsistence farmers

\footnotetext{
${ }^{6}$ Also, a recent productivity report by the World Bank (2020) updated series in existing sectoral datasets, such as the GGDC 10-sector database, using the ILO model-based estimates.

${ }^{7}$ Urban LFS are not representative of the sectoral employment structure in most economies. In particular, if such surveys are used, they may provide unreliable employment estimates in agriculture. For example, for 2010 the agricultural employment share for Argentina in the ILO model-based dataset is 1.3 per cent of the workforce (ilostat.ilo.org accessed September 2020), which compares with a population census-based estimate of 6.0 per cent in the ETD for that year. In the ILO dataset, the agricultural share drops to 0.1 per cent by 2018, whereas it is still 5.1 per cent according to the ETD. This is due to the use of urban LFS by the ILO for Argentina.

${ }^{8}$ See https://ilostat.ilo.org/resources/concepts-and-definitions/ilo-modelled-estimates/.

${ }^{9}$ A report for Rwanda suggests that about 13 per cent of the labour force is no longer considered to be employed in the new definition, and as a result the share of employment in agriculture falls from 68 to 46 per cent (Africa Headline News 2017; see also Gaddis et al. 2020).

${ }^{10}$ National income accounts emphasize the monetary economy, yet an exception is made for the production of primary products. The 1993 SNA recommends including non-monetary (i.e. own use) production of primary products, and this recommendation is upheld in the 2008 SNA (Gaddis et al. 2020; Klasen 2019).
} 
who mostly produce for subsistence but do some non-agricultural activities outside the peak season will now be categorized according to these minor off-farm activities.

Currently it is not clear whether, how, or for which countries and time periods the $19^{\text {th }}$ ICLS standards have been implemented. This problem also applies to the time series of agricultural employment in the WDI, which directly derive from the ILO model-based estimates. The ETD avoids these issues, as it uses the old definition and includes subsistence production workers.

\subsection{Manufacturing data of registered firms and control variables}

In an extension we will examine industrialization conditional on firm size. For this purpose, we use the UNIDO Industrial Statistics Database complemented by industrial surveys available from NSIs (described in detail in Appendix A). We obtain annual data on VA and employment for 2digit manufacturing industries according to ISIC rev. 4 (see Appendix A Table A2) building upon the work by Pahl and Timmer (2019).

The data include information on output and labour input for firms that are sampled from the population of firms recorded in business registers or economic censuses. VA is obtained by subtracting intermediate inputs from sales, which is consistent with the measurement of VA in NA. Usually only firms that surpass an employment threshold or meet registration criteria are included in these surveys. Hence, small unregistered enterprises are typically not included (Pahl and Timmer 2019; Wood 2017). As a result, coverage of small-scale manufacturing activities is limited, even though they can make up a large share of manufacturing employment. We will consider the sum of output and employment from the industrial statistics as pertaining to registered firms. For each country-year, total manufacturing VA and employment of registered firms is subtracted from manufacturing output and employment in the ETD. The residual is defined as output and employment of unregistered small firms.

The regressions control for income and demographic trends. For these, we obtain GDP per capita and population numbers from the Maddison 2020 release (Bolt and van Zanden 2020; Maddison 2020). ${ }^{11}$ In Section 7 we will split the country sample into manufactures exporters and nonmanufactures exporters. We use the BACI database to compute the average manufacturing export and import shares for the period 1995-2018. The BACI database is built from data reported to the United Nations Statistical Division (UN Comtrade) and reconciles declarations of exporting and importing countries (see Gaulier and Zignago 2010).

\section{Re-industrialization? Descriptive trends}

A first step towards understanding industrialization experiences is to map out the share of workers employed in the various sectors of the economy. Figure 1 shows several important changes in the allocation of employment. It shows average agricultural and manufacturing employment shares by region for 1990, 2010, and 2018. These years provide useful decadal demarcations that help relate the descriptive statistics to the regression analysis in subsequent sections. Yet, it is not our intention to interpret observations at 2010 or 2018 as breakpoints in trends observed.

\footnotetext{
${ }^{11}$ Population numbers are reported in 000 s and transformed to actual population numbers (so multiplied by 1,000 ) as in previous studies (e.g. Rodrik 2016).
} 
Figure 1: Employment shares in agriculture and manufacturing, by region

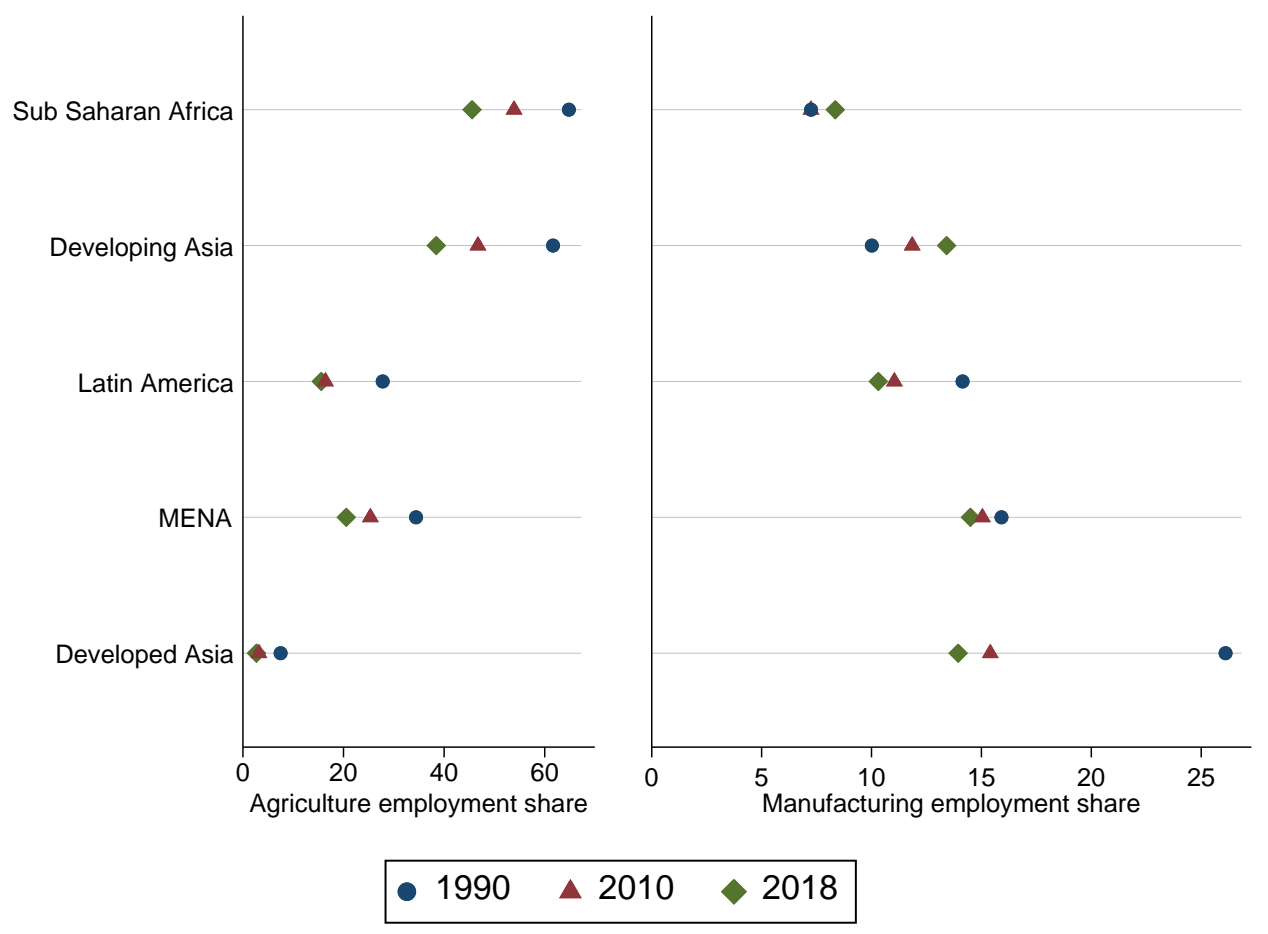

Note: employment shares by region, unweighted averages. See Table 1 for the grouping of countries by region.

Source: authors' calculations using the ETD.

The left panel of Figure 1 shows that the share of employment in agriculture decreased substantially. Between 1990 and 2018 the share of agriculture declined in Latin America from 27.8 to about 15.6 per cent of the workforce; in developing Asia from 61.7 to 38.4 per cent; in MENA from 34.4 to 20.6 per cent; and in sub-Saharan Africa from 64.8 to 45.6 per cent.

What happened to the employment share in manufacturing? The right panel shows trends in manufacturing between 1990 and 2010. In Latin America, the share dropped from 14.1 per cent in 1990 to 11.0 per cent in 2010 and fell further to about 10.3 per cent by 2018. In the MENA countries it declined between 1990 and 2018. Developing Asia defied the trend and saw an increase from 10.0 to 11.9 per cent between 1990 and 2010, and a further increase to 13.4 per cent by 2018 .

Interestingly, in sub-Saharan Africa manufacturing also expanded between 2010 and 2018. The manufacturing employment share was about 7.2 per cent in 1990 and also 7.2 per cent in 2010 . However, after 2010, the share of manufacturing started to rise. On average, it rose by 1.2 percentage points to 8.4 per cent between 2010 and 2018. Although the level of manufacturing activities is low in comparison with that in other regions, the increase in manufacturing in Africa is an important reversal to a long-run de-industrialization trend that was documented for the period from 1960 to 2011 (see e.g. Felipe et al. 2014; Rodrik 2016).

The manufacturing value added (MVA) shares can be calculated at real (constant) or nominal (current) prices. The average real and nominal manufacturing shares in GDP by region are shown in Table 2. Later sections will focus on employment and real MVA, since nominal MVA conflates prices and quantities. 
The real MVA share in advanced Asia increased, despite a decreasing employment share. An opposite pattern is observed in sub-Saharan Africa, where the real MVA share decreased and the employment share increased. These patterns are a testament to differential productivity growth in manufacturing relative to the aggregate economy: above average in advanced Asia and below average in sub-Saharan Africa. Such relative productivity trends carry important implications for economic growth. In sub-Saharan Africa, productivity growth in manufacturing came almost to a standstill at 0.1 per cent on average during the 2010s. This is further explored in Section 7.

Table 2: Manufacturing share in GDP and labour force (\%)

\begin{tabular}{lccccccccc}
\hline & \multicolumn{3}{c}{ Employment } & \multicolumn{3}{c}{ Nominal value added } & \multicolumn{3}{c}{ Real value added } \\
Region & $\mathbf{1 9 9 0}$ & $\mathbf{2 0 1 0}$ & $\mathbf{2 0 1 8}$ & $\mathbf{1 9 9 0}$ & $\mathbf{2 0 1 0}$ & $\mathbf{2 0 1 8}$ & $\mathbf{1 9 9 0}$ & $\mathbf{2 0 1 0}$ & $\mathbf{2 0 1 8}$ \\
Advanced Asia & 26.1 & 15.4 & 13.9 & 24.5 & 19.9 & 19.7 & 17.9 & 19.7 & 19.9 \\
Developing Asia & 10.0 & 11.9 & 13.4 & 16.3 & 19.0 & 18.2 & 14.2 & 18.1 & 18.5 \\
Latin America & 14.1 & 11.0 & 10.3 & 22.0 & 16.5 & 14.9 & 18.7 & 17.1 & 15.4 \\
MENA & 15.9 & 15.0 & 14.5 & 20.5 & 16.8 & 17.5 & 15.9 & 17.4 & 16.6 \\
Sub-Saharan Africa & 7.2 & 7.2 & 8.4 & 15.4 & 11.4 & 10.4 & 12.7 & 11.4 & 10.9 \\
\hline
\end{tabular}

Note: manufacturing share (\%) in employment, nominal GDP, and real GDP by region, unweighted averages. See Table 1 for the grouping of countries by region.

Source: authors' calculations using the ETD.

Figure 2 displays the manufacturing employment share by country. The left panel shows the share in 1990 versus 2010, whereas the right panel shows the share in 2010 versus 2018. The dashed line is a 45-degree line, whereas the solid line provides a linear fit for all observations. The left panel suggests that manufacturing trends varied considerably across countries between 1990 and 2010 . Yet, most observations fall below the 45-degree line and the coefficient from the regression is below 1 . This suggests that de-industrialization is observed on average.

The right panel shows trends between 2010 and 2018. The manufacturing share in 2018 is close to that in 2010. Observations are close to the diagonal and the regression coefficient is close to 1 . In fact, for many countries manufacturing activities increased. The diamonds-observations for developing Asian countries - are often above the 45-degree line, which suggests industrialization, e.g. in Bangladesh and Viet Nam. Yet, many squares-observations for sub-Saharan African countries-are also above the diagonal. For sub-Saharan Africa this includes countries such as Burkina Faso, Kenya, and Senegal.

Finally, Figure 3 singles out the industrialization experience of selected countries, namely Bangladesh, China, Kenya, Mexico, Senegal, and Viet Nam. Starting with China, the country with the largest number of manufacturing workers, we see that the country's industrialization experience includes a declining share in the late 1990s due to the downsizing of state-owned enterprises, and the rapid expansion of manufacturing in the 2000s as China entered the WTO (Bosworth and Collins 2008). From 2007 onwards, the manufacturing employment share remained stable at around 20 per cent.

In Bangladesh, manufacturing expanded from 2000 onwards and in 2018 was slightly above the levels observed in the early 1990s. For Kenya and Senegal, we also observe an increase in manufacturing, although starting at low levels. In Mexico, we observe a reversal in deindustrialization after 2009, although manufacturing activity is still below the levels observed in the early 1990s. Finally, manufacturing expanded throughout the period in Viet Nam, and was close to the level in China by 2018. 
Figure 2: Employment shares in manufacturing, 1990, 2010, 2018
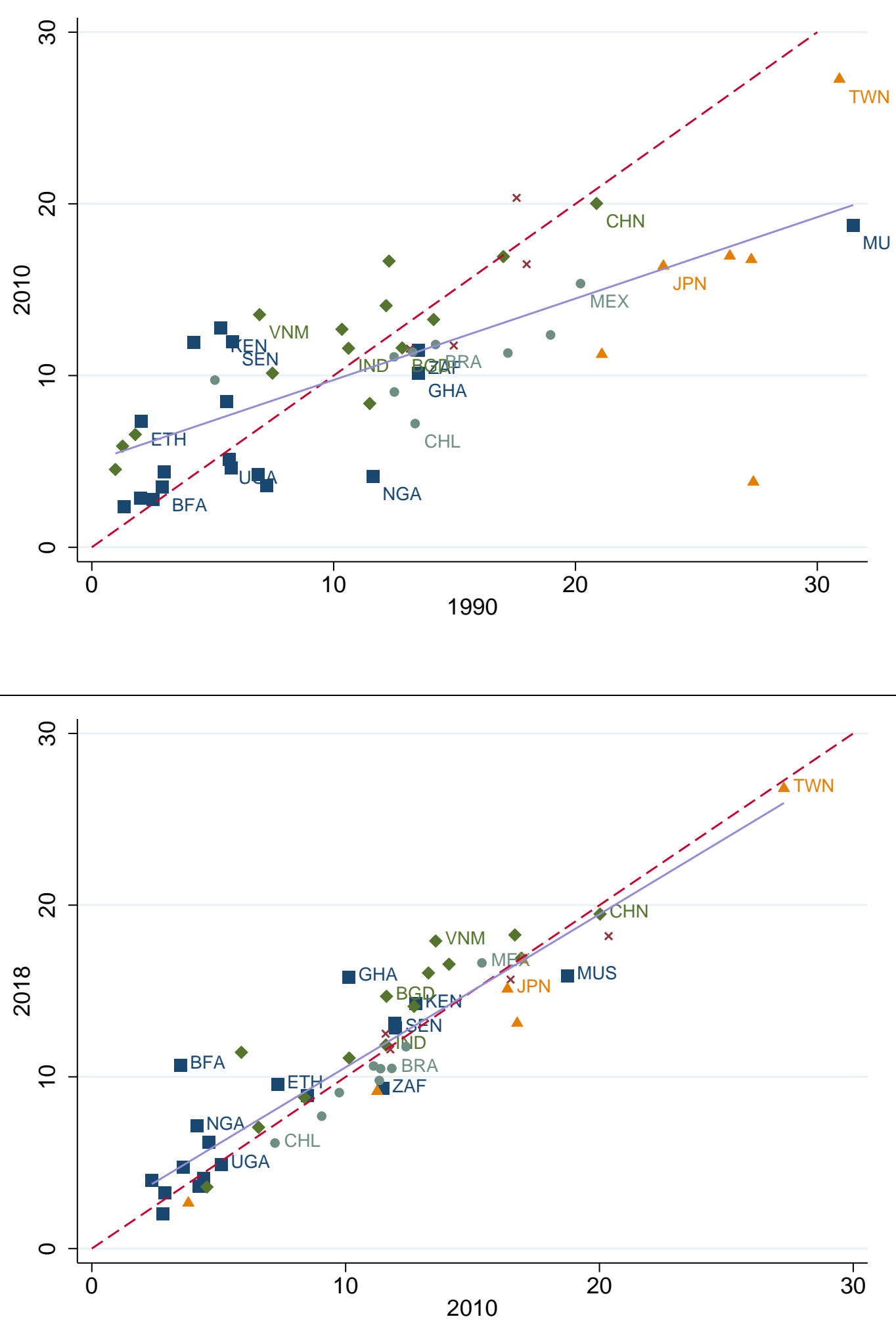

Note: squares refer to sub-Saharan African countries, diamonds to developing Asian countries, crosses to MENA countries, triangles to advanced Asian countries, and circles to Latin American countries. The dashed line is a 45-degree line, whereas the solid line provides a linear fit. See Table 1 for the grouping of countries by region. Source: authors' calculations using the ETD. 


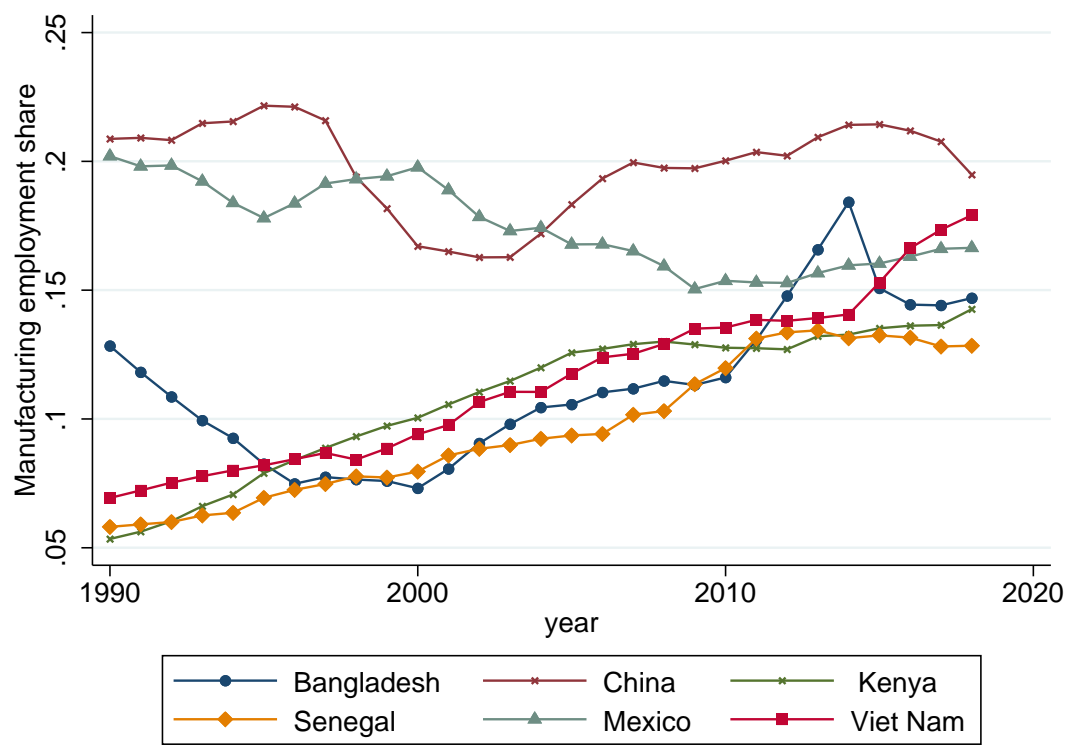

Source: authors' calculations using the ETD.

In a nutshell, these descriptive statistics point to employment industrialization for many developing countries, in particular in developing Asia and sub-Saharan Africa. The next sections examine these trends more formally.

\section{$4 \quad$ Methodology}

To investigate industrialization trends in developing countries, we consider an empirical model which controls for income and population effects. Controlling for these covariates is relevant, because the reallocation of economic activity across sectors is partly driven by changes in demand from rising real income. From a theoretical perspective, structural change driven by nonhomothetic tastes is typically modelled using a Stone-Geary utility function, which generates nonlinear Engel curves. ${ }^{12}$ In this framework, the marginal rate of substitution between different goods is conditional on income and induces reallocation towards manufacturing products and services as income rises. The extended version of Engel's law shows that the budget share spent on manufacturing goods increases during the initial stages of development, then stabilizes, and eventually falls beyond a certain level of per capita income. Therefore, we expect a hump-shaped relationship between per capita income and the manufacturing output/employment share, which we aim to capture by including the square of income per capita in the econometric model.

A large domestic market is indicative of potential demand, although the extent of the demand will depend upon the level of income. That is, for a given level of income, a higher population is associated with a larger market. We expect a rising population to increase the demand for manufactures, with manufacturing firms responding by producing more manufactures at a lower cost per unit, thanks to scale economies. As the unit cost of manufactures falls, firms become

\footnotetext{
${ }^{12}$ Comin et al. (2021) derive a hump-shaped relationship between manufacturing and per capita income using a nonhomothetic CES utility function that generates log-linear Engel curves. See also Herrendorf et al. (2014).
} 
more competitive domestically and internationally, leading to further increases in demand and further expansion of manufacturing activities. Thus, we expect a positive relationship between population and manufacturing output/employment. Beyond a certain threshold, population growth may become a drag on manufacturing. For example, if agricultural consumption surges as a result of high population growth, industry might be denied critical raw materials (Zhou 2009). We follow Rodrik (2016) and also include the square of population in the econometric model.

The baseline econometric model follows Chenery (1960), popularized by Rodrik (2016): ${ }^{13}$

$$
\begin{array}{r}
\text { Mshare }_{i t}=\beta_{0}+\beta_{1} \ln \mathrm{Y}_{i t}+\beta_{2}(\ln Y)_{i t}^{2}+\beta_{3} \ln P_{i t}+ \\
\beta_{4}(\ln P)_{i t}^{2}+\gamma P D_{t}+\alpha_{i}+\varepsilon_{i t}
\end{array}
$$

where Mshare $_{i t}$ is the manufacturing employment or output share for country $i$ at time $t, \beta_{0}$ is the constant, $\ln Y$ and $(\ln Y)^{2}$ are the natural logarithm of per capita income and its squared value, $\operatorname{In} P$ and $(\operatorname{In} P)^{2}$ are the natural logarithm of population and its squared value, and $\alpha_{i}$ are country-fixed effects that take into account any time-invariant country-specific features such as geography, endowments, and history, that might generate a varying degree of industrialization across countries relative to baseline conditions.

We aim to capture industrialization patterns using period dummies $\left(P D_{t}\right)$ for the 2000 s, and the 2010-18 years. The estimated coefficients of the period dummies show the manufacturing (output and employment) share of each period relative to the excluded decade of the 1990s. In an extension, we will estimate (1) using year dummies instead of period dummies.

We also estimate regressions to explore heterogeneity in industrialization trends by interacting the period dummies with country- (or region-) fixed effects using:

$$
\begin{aligned}
\text { Mshare }_{i t}=\beta_{0}+\beta_{1} \ln \mathrm{Y}_{i t}+\beta_{2}(\ln Y)_{i t}^{2}+\beta_{3} \ln P_{i t}+ \\
\beta_{4}(\ln P)_{i t}^{2}+\gamma P D_{t}+\delta P D_{t} \times d_{i=c}+\alpha_{i}+\varepsilon_{i t}
\end{aligned}
$$

where $P D_{t} \times d_{i=c}$ is the period dummy (PD) interacted with a dummy for the country (or region) of interest $\left(\mathrm{d}_{\mathrm{i}=\mathrm{c}}=1\right.$ and $\left.\mathrm{d}_{\mathrm{i} \neq \mathrm{c}}=0\right)$. The coefficient $\delta$ of the interaction indicates how much of the period dummy varies by region or country, holding income and population effects constant. This interaction effect $\delta$ is a comparison of the industrialization pattern in a country (or region) relative to the trend in the full sample. The direct effect $\gamma$ is the global average trend excluding the country (or region) for which $\mathrm{d}_{\mathrm{i}=\mathrm{c}}=1$. We calculate the marginal (or net) industrialization effect by combining the direct and the interaction effects $(\delta+\gamma)$. The standard error of this marginal effect is calculated using the delta-method Taylor approximation.

We closely follow Rodrik (2016) and estimate (1) and (2) using OLS fixed effects regressions with (heteroskedasticity) robust standard errors.

\section{$5 \quad$ Baseline regression results}

This section presents baseline regressions for employment and output industrialization. We run regressions for the global sample as well as by region.

\footnotetext{
${ }^{13}$ Note that Chenery (1960) did not include the square of income and population in his model.
} 
Table 3 reports results for manufacturing employment shares using (1). The key parameters of interest are those for the decade-fixed effects of the manufacturing share in the 2000s and 2010s, which are estimated relative to the 1990s. The first column shows this in the aggregate sample. Subsequent columns show regressions by region. In column (2) we find that de-industrialization continued in advanced Asian economies, which become increasingly services oriented. The pattern is different for developing Asian countries, shown in column (3). The 2010 decadal dummy is positive and significant, suggesting employment industrialization. For Latin America, we find significant de-industrialization in the 2000s. The coefficient for the 2010s is also negative but not significant, as in the aggregate sample.

Table 3: Baseline regressions, manufacturing employment share

\begin{tabular}{|c|c|c|c|c|c|c|}
\hline & $\begin{array}{c}\text { All } \\
\text { countries }\end{array}$ & $\begin{array}{c}\text { Advanced } \\
\text { Asia }\end{array}$ & $\begin{array}{l}\text { Developing } \\
\text { Asia }\end{array}$ & $\begin{array}{l}\text { Latin } \\
\text { America }\end{array}$ & $\begin{array}{l}\text { Sub- } \\
\text { Saharan } \\
\text { Africa }\end{array}$ & $\begin{array}{c}\text { Sub- } \\
\text { Saharan } \\
\text { Africa (excl. } \\
\text { Mauritius) }\end{array}$ \\
\hline & (1) & (2) & (3) & (4) & (5) & (6) \\
\hline In population & $\begin{array}{r}-0.204^{\star \star \star} \\
(0.047)\end{array}$ & $\begin{array}{r}0.775 \\
(0.629)\end{array}$ & $\begin{array}{r}0.127 \\
(0.078)\end{array}$ & $\begin{array}{r}-0.596^{\star \star *} \\
(0.061)\end{array}$ & $\begin{array}{r}-0.018 \\
(0.080)\end{array}$ & $\begin{array}{r}0.055 \\
(0.073)\end{array}$ \\
\hline In population squared & $\begin{array}{r}0.006^{\star \star *} \\
(0.001)\end{array}$ & $\begin{array}{r}-0.029 \\
(0.021)\end{array}$ & $\begin{array}{r}-0.005^{\star \star} \\
(0.002)\end{array}$ & $\begin{array}{c}0.018^{\star \star \star} \\
(0.003)\end{array}$ & $\begin{array}{r}0.002 \\
(0.002)\end{array}$ & $\begin{array}{r}-0.001 \\
(0.002)\end{array}$ \\
\hline In GDP per capita & $\begin{array}{r}0.386^{\star \star \star} \\
(0.021)\end{array}$ & $\begin{array}{r}0.626 \\
(0.437)\end{array}$ & $\begin{array}{c}0.300^{\star \star \star} \\
(0.041)\end{array}$ & $\begin{array}{c}0.965^{\star \star \star} \\
(0.110)\end{array}$ & $\begin{array}{r}0.326^{\star \star \star} \\
(0.040)\end{array}$ & $\begin{array}{r}0.235^{\star \star \star} \\
(0.032)\end{array}$ \\
\hline In GDP per capita squared & $\begin{array}{r}-0.023^{\star \star \star} \\
(0.001)\end{array}$ & $\begin{array}{r}-0.030 \\
(0.021)\end{array}$ & $\begin{array}{r}-0.016^{\star \star \star} \\
(0.002)\end{array}$ & $\begin{array}{r}-0.056^{\star * *} \\
(0.006)\end{array}$ & $\begin{array}{r}-0.023^{\star \star *} \\
(0.003)\end{array}$ & $\begin{array}{r}-0.017^{\star \star \star} \\
(0.002)\end{array}$ \\
\hline $2000 s$ & $\begin{array}{r}-0.005^{\star \star \star} \\
(0.002)\end{array}$ & $\begin{array}{r}-0.037^{\star \star *} \\
(0.006)\end{array}$ & $\begin{array}{r}0.004 \\
(0.003)\end{array}$ & $\begin{array}{r}-0.011^{\star * *} \\
(0.003)\end{array}$ & $\begin{array}{r}-0.002 \\
(0.003)\end{array}$ & $\begin{array}{c}0.005^{\star} \\
(0.003)\end{array}$ \\
\hline 2010s & $\begin{array}{r}-0.003 \\
(0.003)\end{array}$ & $\begin{array}{r}-0.048^{\star \star \star} \\
(0.007)\end{array}$ & $\begin{array}{l}0.010^{\star *} \\
(0.005)\end{array}$ & $\begin{array}{r}-0.008 \\
(0.005)\end{array}$ & $\begin{array}{r}0.005 \\
(0.006)\end{array}$ & $\begin{array}{r}0.019 * * \star \\
(0.004)\end{array}$ \\
\hline Country-fixed effects & Yes & Yes & Yes & Yes & Yes & Yes \\
\hline Countries & 51 & 6 & 14 & 9 & 18 & 17 \\
\hline Observations & 1,479 & 174 & 406 & 261 & 522 & 493 \\
\hline $\mathrm{R}^{2}$ & 0.91 & 0.87 & 0.92 & 0.89 & 0.89 & 0.84 \\
\hline
\end{tabular}

Note: dependent variable is the manufacturing employment share. Regressions estimated using (1). Robust standard errors in parentheses. See Table 1 for the country groupings. Developing Asia corresponds to the IMF (2020) country grouping 'Emerging and Developing Asia'. The results for the four countries from the MENA region are not reported separately, but included in the full sample in column (1). ${ }^{\star} p<0.10,{ }^{\star \star} p<0.05,{ }^{\star \star \star} p<0.01$.

Source: authors' calculations.

Results for sub-Saharan Africa with and without Mauritius are shown in columns 5 and $6 .{ }^{14}$ The estimates suggest that the average economy in sub-Saharan Africa (excluding Mauritius) had a manufacturing employment share about 1.9 percentage points higher in the 2010s than in the 1990s. Rodrik (2016) found that the sub-Saharan African manufacturing share declined by 3.5 percentage points during the period from 1960 to 2010. Our point estimate thus suggests a recovery of manufacturing by more than half the downward shift observed in the decades before.

Table 4 reports results for real MVA shares. The period dummies indicate that output shares were stable over time. That is, for each region we observe neither a significant industrialization nor a significant de-industrialization trend. In contrast—as in Rodrik (2016)—-the decade-fixed effects

\footnotetext{
${ }^{14}$ Mauritius has a much higher GDP per capita than other sub-Saharan African countries and experienced a strong de-industrialization trend (see Section 6), which is why we follow Rodrik (2016) and present additional results for subSaharan Africa excluding Mauritius.
} 
for MVA share in current prices (see Appendix B Table B1) suggest de-industrialization. The absence of a global downward trend in MVA in constant prices suggests a slower price increase in manufacturing relative to other sectors.

Table 4: Baseline regressions, real manufacturing value added shares

\begin{tabular}{|c|c|c|c|c|c|c|}
\hline & $\begin{array}{c}\text { All } \\
\text { countries }\end{array}$ & $\begin{array}{l}\text { Advanced } \\
\text { Asia }\end{array}$ & $\begin{array}{l}\text { Developing } \\
\text { Asia }\end{array}$ & $\begin{array}{l}\text { Latin } \\
\text { America }\end{array}$ & $\begin{array}{c}\text { Sub- } \\
\text { Saharan } \\
\text { Africa }\end{array}$ & $\begin{array}{c}\text { Sub- } \\
\text { Saharan } \\
\text { Africa excl. } \\
\text { Mauritius }\end{array}$ \\
\hline & (1) & (2) & (3) & (4) & (5) & (6) \\
\hline \multirow[t]{2}{*}{ In population } & $-0.300^{\star \star \star}$ & $-0.847^{*}$ & $-0.521^{\star \star}$ & $-0.786^{\star \star \star}$ & $0.312^{\star \star \star}$ & $0.361^{\star \star \star}$ \\
\hline & (0.068) & $(0.489)$ & $(0.232)$ & $(0.086)$ & $(0.099)$ & $(0.096)$ \\
\hline \multirow[t]{2}{*}{ In population squared } & $0.008^{\star * *}$ & 0.020 & $0.014^{\star \star}$ & $0.023^{\star \star \star}$ & $-0.009 * \star \star$ & $-0.011^{\star \star *}$ \\
\hline & $(0.002)$ & $(0.016)$ & $(0.006)$ & $(0.003)$ & $(0.003)$ & $(0.003)$ \\
\hline \multirow[t]{2}{*}{ In GDP per capita } & -0.000 & 0.476 & $0.202^{\star \star \star}$ & $0.747^{\star \star \star}$ & $0.195^{\star \star \star}$ & $0.138^{\star * *}$ \\
\hline & $(0.031)$ & $(0.335)$ & $(0.062)$ & $(0.084)$ & $(0.045)$ & $(0.041)$ \\
\hline \multirow[t]{2}{*}{ In GDP per capita squared } & 0.001 & -0.017 & $-0.010^{\star \star}$ & $-0.042^{\star \star \star}$ & $-0.014^{\star \star \star}$ & $-0.011^{\star \star *}$ \\
\hline & $(0.002)$ & $(0.016)$ & $(0.004)$ & $(0.005)$ & $(0.003)$ & $(0.003)$ \\
\hline \multirow[t]{2}{*}{$2000 s$} & $0.005^{\star \star \star}$ & -0.001 & -0.002 & 0.002 & 0.001 & $0.006^{*}$ \\
\hline & $(0.002)$ & $(0.004)$ & $(0.005)$ & $(0.003)$ & $(0.003)$ & $(0.003)$ \\
\hline \multirow[t]{2}{*}{$2010 s$} & -0.001 & 0.000 & -0.011 & -0.007 & -0.003 & 0.006 \\
\hline & $(0.003)$ & $(0.005)$ & $(0.009)$ & $(0.005)$ & $(0.005)$ & $(0.005)$ \\
\hline Country-fixed effects & Yes & Yes & Yes & Yes & Yes & Yes \\
\hline Countries & 51 & 6 & 14 & 9 & 18 & 17 \\
\hline Observations & 1,479 & 174 & 406 & 261 & 522 & 493 \\
\hline $\mathrm{R}^{2}$ & 0.88 & 0.96 & 0.84 & 0.96 & 0.86 & 0.86 \\
\hline
\end{tabular}

Note: dependent variable is the manufacturing value added share in constant prices. Regressions estimated using equation (1). Robust standard errors in parentheses. See Table 1 for the country groupings. Developing Asia corresponds to the IMF (2020) country grouping 'Emerging and Developing Asia'. The results for the four countries from the MENA region are not reported separately, but included in the full sample in column (1). * $\mathrm{p}<0.10,{ }^{* *} \mathrm{p}<0.05,{ }^{* \star *} \mathrm{p}<0.01$.

Source: authors' calculations.

Decade dummies are commonly used to avoid fluctuations arising from business cycles. Yet, since the dependent variable is observed annually, decade dummies may assign annual idiosyncrasies in manufacturing employment or production within each decade to other (annual) explanatory variables. As a result, specifications with decade dummies may underreport actual trends.

Figure 4 reports coefficients and their confidence intervals for time trends identified by estimating (1) with year-fixed effects and employment as the dependent variable. We examine the same regions as above. The specification with year dummies indicates a significant de-industrialization trend in Latin America. Results for other regions are congruent with those with decadal dummies, namely de-industrialization in advanced Asia, industrialization in developing Asia and sub-Saharan Africa (excluding Mauritius).

The point estimates inform on the timing of industrialization patterns. For sub-Saharan Africa, the point estimates are significantly above the initial (1990) manufacturing level from 2003 onwards. 
Figure 4: Annual time trend manufacturing employment share by region
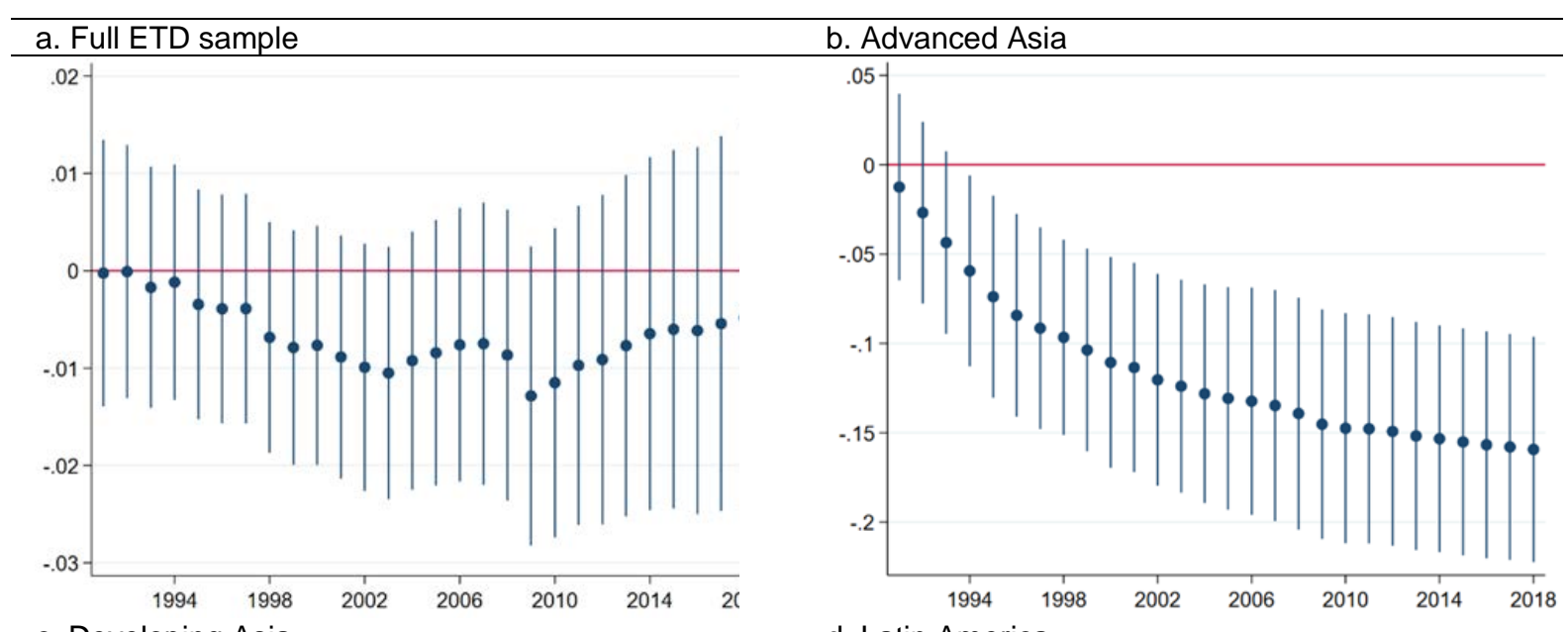

c. Developing Asia

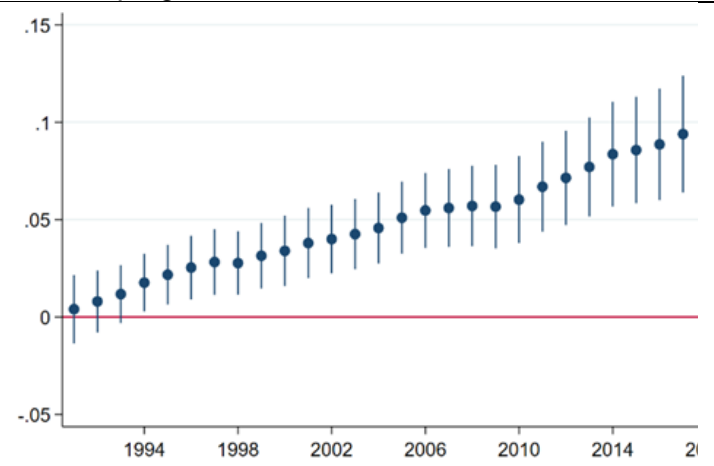

d. Latin America

e. Sub-Saharan Africa

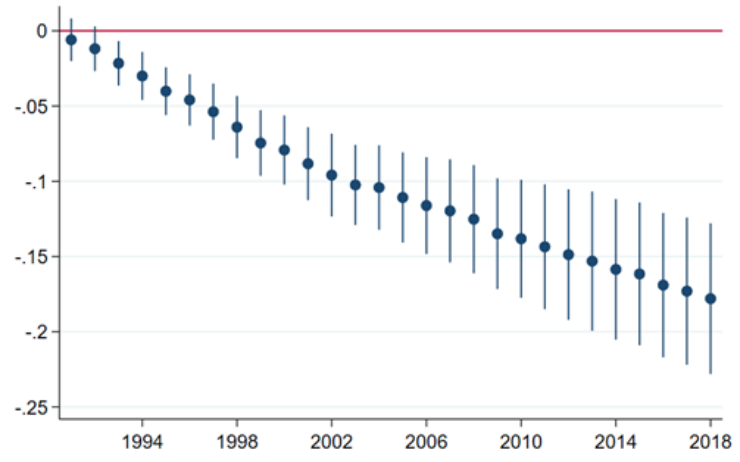

f. Sub-Saharan Africa (excluding Mauritius)
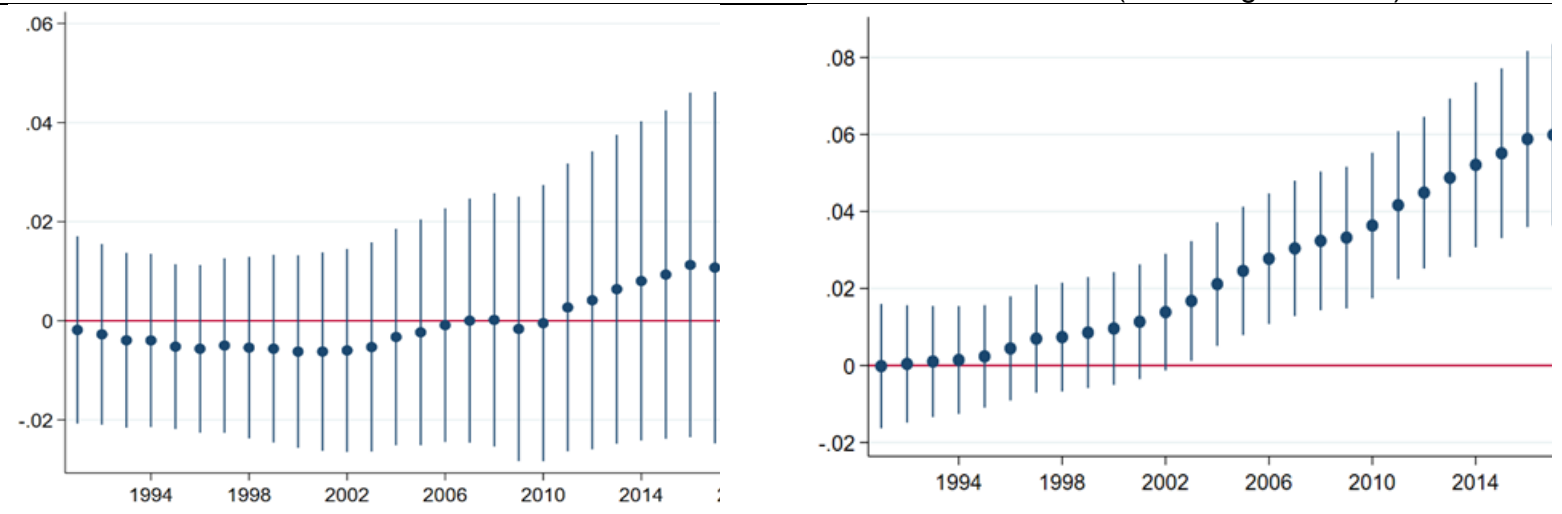

Notes: dependent variable is the manufacturing employment share. Shown are coefficient estimates of the year dummies and their 95\% confidence intervals using (1).

Source: authors' calculations.

\section{$6 \quad$ Industrialization trends across countries}

This section documents heterogeneity in industrialization across countries. In subsection 6.1 we compare our results with Rodrik (2016). When we estimate (1) for the smaller sample of subSaharan African countries in Rodrik (2016), there is no significant industrialization trend in the 2010s. This suggests that results are sensitive to country coverage. Subsection 6.2 digs deeper by studying regional and country-specific industrialization patterns. 


\subsection{A comparison with Rodrik (2016)}

The recent expansion in manufacturing employment, in particular in sub-Saharan Africa, contrasts with findings of de-industrialization by Rodrik (2016). Why do the findings differ? First, the analysis in Rodrik (2016) is based on a larger panel dataset including pre-1990 observations. Second, Rodrik (2016) uses a smaller set of countries. Third, the ETD uses more recent national accounts data and new employment sources. Coverage of new (often small-scale manufacturing and services) activities tends to improve if new surveys and censuses are conducted. Hence, the findings could also differ due to data vintages.

We examine these potential explanations in Table 5. As before, the dependent variable is the manufacturing employment share. Regressions are estimated using (1). Only results of the decadal dummy for the 2010s are shown. Column (1) reproduces the baseline findings. In Column (2) observations before 1990 are included by extrapolating the ETD series backwards using the 10SD and the Extended Africa Sector Database (EASD). In column (3) the country sample is restricted to countries included in the 10SD used by Rodrik (2016). In Column (4), the time series for the 10SD countries are updated using trends from the ETD, hence retaining levels of economic activity reported in the $10 \mathrm{SD}$.

Table 5: Sample heterogeneity and data vintages

\begin{tabular}{|c|c|c|c|c|}
\hline & (1) & (2) & (3) & (4) \\
\hline \multicolumn{5}{|l|}{ Sub-Saharan Africa (excluding Mauritius) } \\
\hline \multirow[t]{2}{*}{$2010 s$} & $.0194^{\star \star \star}$ & $.0147^{\star \star \star}$ & .0079 & -.0046 \\
\hline & $(.0045)$ & $(.0042)$ & $(.0058)$ & $(.0038)$ \\
\hline \multicolumn{5}{|l|}{ Latin America } \\
\hline \multirow[t]{2}{*}{ 2010s } & -.0079 & $-.0449^{\star \star \star}$ & $-.0092^{\star}$ & $-.0116^{\star \star}$ \\
\hline & $(.0053)$ & $(.0046)$ & $(.0054)$ & $(.0054)$ \\
\hline \multicolumn{5}{|l|}{ Developing Asia } \\
\hline \multirow[t]{2}{*}{$2010 s$} & $.0100^{\star *}$ & $-.0132^{\star \star \star}$ & -.0058 & .0004 \\
\hline & $(.0045)$ & $(.0050)$ & $(.0075)$ & $(.0067)$ \\
\hline Full ETD country sample & Yes & No & No & No \\
\hline Including observations pre-1990 & No & Yes & No & No \\
\hline 10SD country sample used in Rodrik (2016) & No & No & Yes & Yes \\
\hline 10SD levels updated to 2018 & No & No & No & Yes \\
\hline
\end{tabular}

Note: dependent variable is the manufacturing employment share. Regressions are estimated using (1). Only the 2010 decadal dummies are shown. Robust standard errors in parentheses. Column (1) shows the baseline findings. In column (2) the ETD series are extrapolated backwards using the 10SD and the EASD. In Column (3) the country sample is restricted to countries included in the 10SD used by Rodrik (2016). In Column (4) the country sample is also restricted to countries included in the 10SD. In addition, the time series in the 10SD were updated using the trends from the ETD. Venezuela is not in the ETD. It is included in the regressions in columns (2) and (3) but with time series that stop in 2011. ${ }^{*} p<0.10,{ }^{* *} p<0.05,{ }^{* *} p<0.01$.

Source: authors' calculations.

Consider the comparison for sub-Saharan Africa. First, column (2) extends the sample by including pre-1990 observations. This does not substantially change the baseline results. Next, note that 18 sub-Saharan African countries are included in the ETD. Of these, 11 are included in the 10SD. Column (3) restricts the country sample to those in the 10SD. ${ }^{15}$ This results in a positive yet insignificant industrialization trend for sub-Saharan Africa. It suggests that the results of Rodrik (2016) are sensitive to sample heterogeneity. Indeed, for several of the additional sub-Saharan

\footnotetext{
${ }^{15}$ Note that ex ante one might expect that enlarging the set of countries would diminish the probability of observing industrialization, given that the 10SD tends to include more successful countries.
} 
African countries in the ETD we observe industrialization. Some countries, such as Burkina Faso, Cameroon, Lesotho, and Mozambique, experience industrialization patterns that significantly exceed the global average trend (discussed in Section 6.2). The inclusion of these countries in column 1 appears to drive the significant industrialization trend in the 2010s.

Column (4) reports results where the country sample is restricted and in addition the old 10SD levels are used. The coefficient of the 2010 decadal dummy for sub-Saharan Africa now turns negative, as in Rodrik (2016). Indeed, the closer we move towards the data used by Rodrik (2016), the closer we get to reproducing his results. When we also use the vintage of the control variables in Rodrik (2016), we find that the 2010s decadal dummy is -0.018 and statistically significant at the 1 per cent level (relative to the 1990s). ${ }^{16}$

For Latin America, the inclusion of pre-1990 observations in column (2) reproduces the deindustrialization trend in Rodrik (2016). The sample of countries is comparable, the only difference being that Ecuador is included in and Venezuela excluded from the ETD in comparison with the 10SD. Hence, the results in column (3) for the restricted country sample are comparable to the baseline in column (1). Using the 10SD levels in column (4) also only slightly alters the results. In line with the annual time trend reported in Section 5, de-industrialization appears as the typical pattern in Latin America.

A comparison of the results for Asia is more difficult. This is because only a few (6 out of 14) developing Asian countries are in the 10SD used by Rodrik (2016). That is, long-run time series for many developing Asian countries in the ETD are not available, so the coefficient for developing Asia in column (2) is reported for completeness but is difficult to interpret. It is only for these six developing Asian countries that we can extend the series backwards and do the analysis presented in column (2). This contrasts with the analysis for 14 countries included in column (1). Column (3) suggests that the results for developing Asia are also sensitive to country coverage, as the industrialization trend is insignificant in the smaller country set. The ETD includes several countries that have industrialized, such as Cambodia and Viet Nam, which appear to drive the significant industrialization trend shown in column (1). Finally, column (4) suggests that the use of 10SD levels is not driving the differences in results.

\subsection{Region- and country-specific industrialization patterns}

This subsection goes a step further and examines industrialization patterns in countries and regions. We estimate (2), where we interact the region-fixed effect with decadal dummies. Similarly, we estimate (2) for each country, where we interact the country-fixed effect with decadal dummies. The interaction effect is a comparison of the industrialization pattern in a country (or region) relative to the trend in the full sample. The direct effect in (2) is the global average trend excluding the focal country (or region). Combining both the direct and the interaction effects allows us to calculate the marginal (or net) industrialization effect. ${ }^{17}$

\footnotetext{
${ }^{16}$ Cf. table 4 in Rodrik (2016). Rodrik uses the Maddison (2009) release and updates income and population data with the World Bank's World Development Indicators. For sub-Saharan Africa there have been large data revisions by statistical offices in recent years. For example, Nigeria's GDP revision in 2013 led to an almost doubling of its economy. This affects GDP per capita, one of the variables in (1).

${ }^{17}$ We assume that the full sample is representative of the global average trend. This subsection discusses only results for manufacturing employment and abstracts from trends in MVA. Appendix B Table B3 provides results for real MVA. Cross-country heterogeneity in employment industrialization is also observed for MVA.
} 
We start by reporting the marginal effect by region. Figure 5 shows industrialization trends in the 2000s and 2010s relative to the 1990s. On average, developing Asia experienced roughly a 2 percentage point increase in manufacturing employment share from the 1990s. Sub-Saharan Africa also industrialized: its share of manufacturing workers was about 0.7 percentage points higher in the 2010s than in the 1990s, and statistically significant at the 10 per cent level. ${ }^{18}$ In Latin America, the share of manufacturing workers has been decreasing over the last two decades. Note, however, that de-industrialization mainly occurs in the 2000s. Finally, the manufacturing share in advanced Asia declined by 3.7 percentage points relative to the 1990 s.

Figure 5: Industrialization patterns by region relative to the 1990s

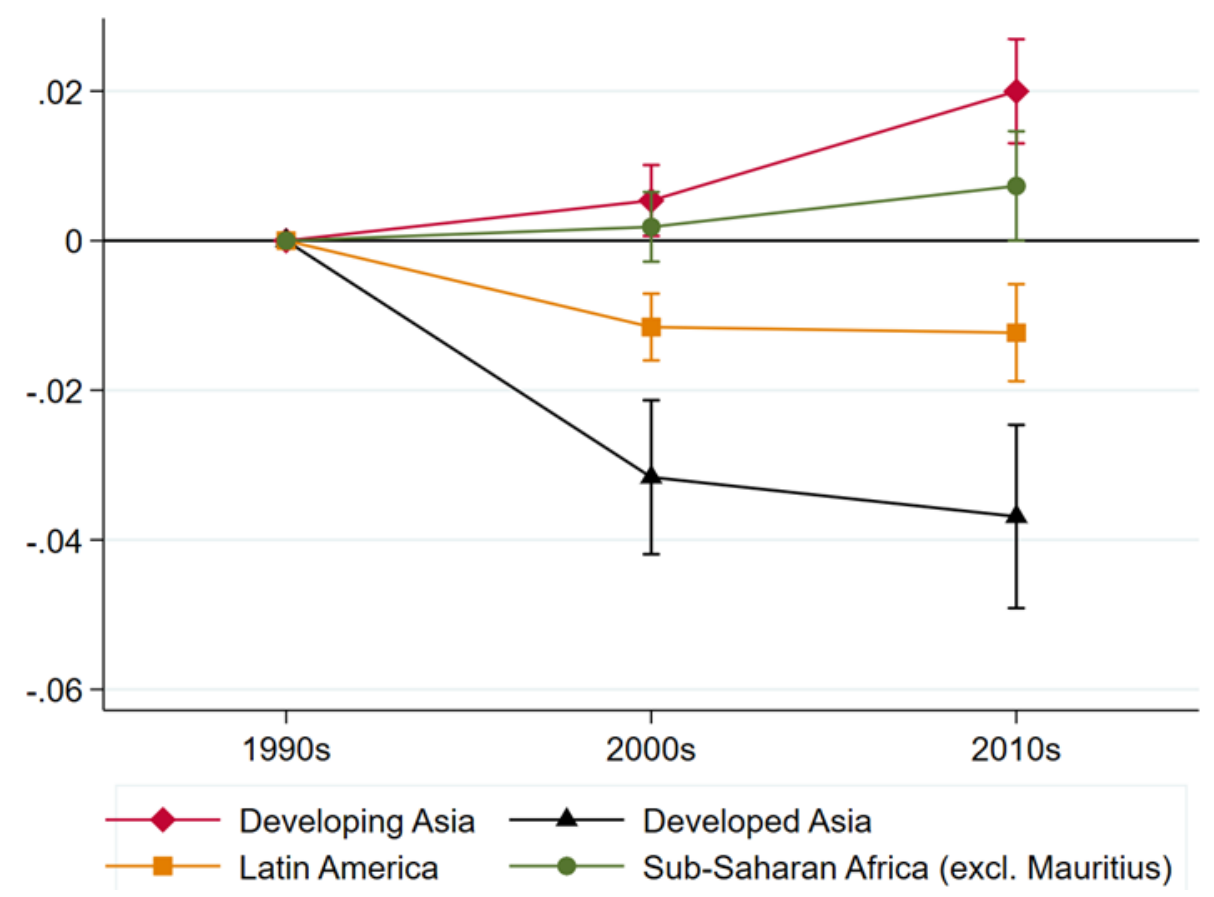

Note: dependent variable is the manufacturing employment share. Marginal effects by region are shown. Each marginal effect is estimated on the basis of a separate regression using (2). The $95 \%$ confidence intervals are derived using the delta-method Taylor approximation for standard errors of marginal effects. Estimation results are reported in Appendix B Table B2.

Source: authors' calculations.

Figure 6 displays industrialization trends for 12 countries. Each row shows four countries in Latin America, Asia, and sub-Saharan Africa, respectively. It illustrates that some countries in each region were industrializing even if the region on average was de-industrializing. For example, in Latin America manufacturing expanded in Bolivia, and in advanced Asia manufacturing expanded in Chinese Taipei. Conversely, in every region we also observe countries that de-industrialized, such as Philippines in developing Asia. Figure 6 also illustrates the rapid decline in manufacturing employment in Mauritius, which is why we follow Rodrik (2016) and exclude it in part of the analysis for sub-Saharan Africa. Finally, Figure 6 illustrates a reversal in industrialization trends for some countries. For example, de-industrialization in Argentina, Bangladesh, and Ghana in the 2000s did not continue in the 2010s. In Kenya and Bolivia, industrialization stalled in the 2010s.

\footnotetext{
${ }^{18}$ If we include Mauritius, the manufacturing employment share for sub-Saharan Africa in the 2010s is not significantly different from the 1990s.
} 
Figure 6: Trend in manufacturing employment share, selected countries.
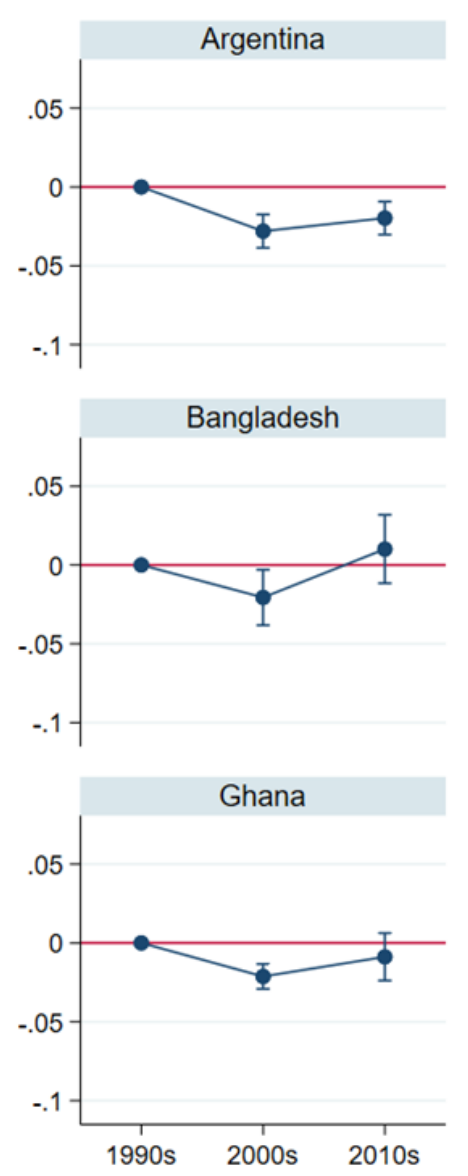

Bolivia

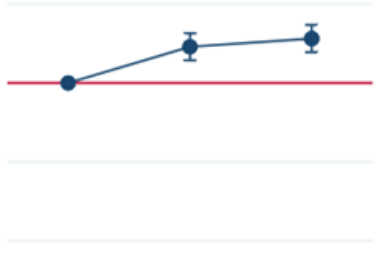

Philippines
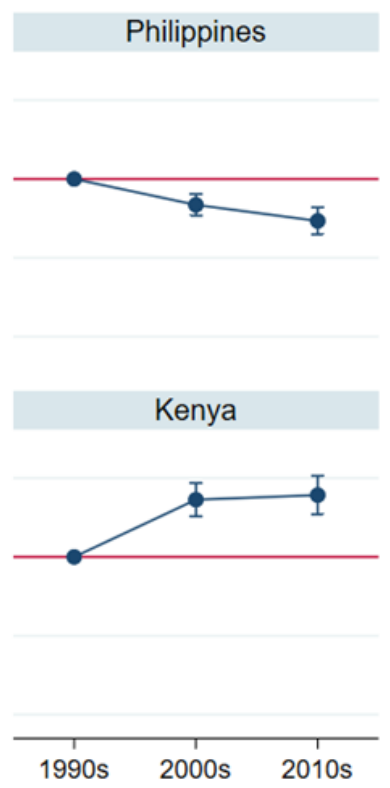

Costa Rica
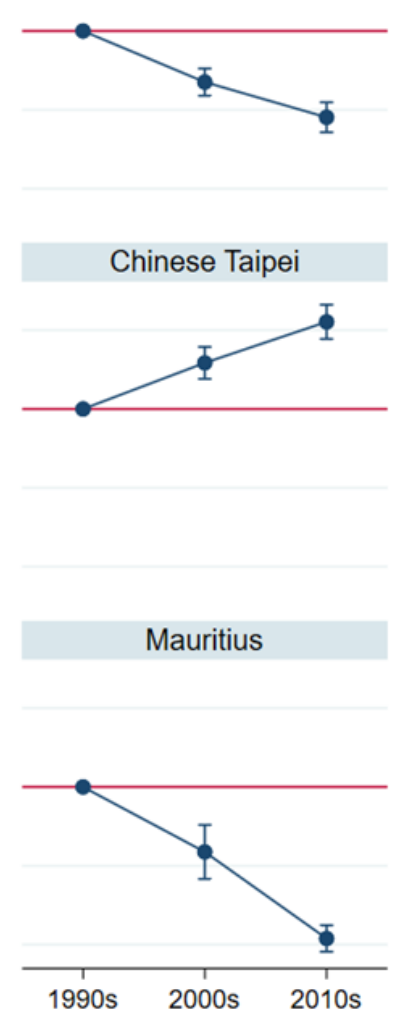

Peru
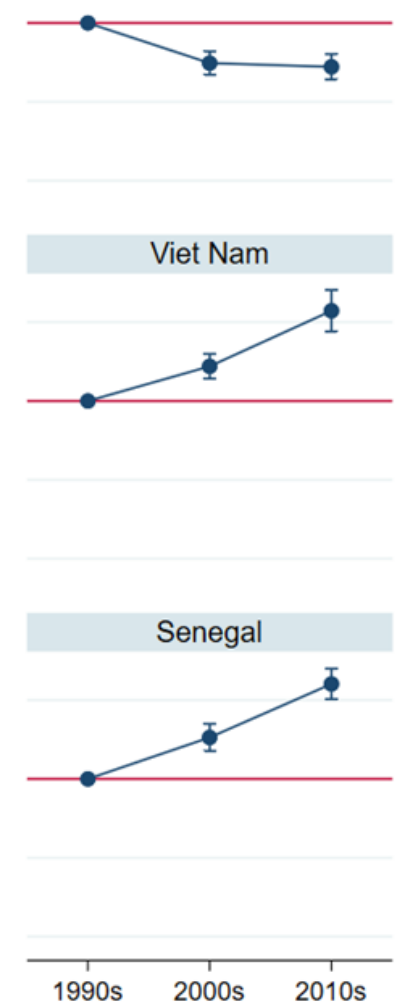

Notes: dependent variable is the manufacturing employment share. Marginal effects by country are shown. Each marginal effect is estimated on the basis of a separate regression using (2). The $95 \%$ confidence intervals are based on the delta-method Taylor approximation for standard errors of marginal effects. Estimation results are reported in Appendix B Table B2.

Source: authors' calculations.

Figure 7 shows results for all countries included in the ETD. As before, we show the marginal effect of the country-specific manufacturing employment share in the 2010s relative to the 1990s. Countries are sorted on the basis of the size of the observed change. The figure illustrates substantial cross-country heterogeneity in industrialization patterns. Countries with a significantly higher share of manufacturing workers in sub-Saharan Africa include Burkina Faso, Cameroon, Kenya, Lesotho, Mozambique, and Senegal. For developing Asia, these include Cambodia, Indonesia, Sri Lanka, Thailand, and Viet Nam. Furthermore, industrial development is observed in Bolivia and Turkey.

This heterogeneity within regions and across decades is important for the interpretation of broader regional trends. Our findings illustrate that industrialization is possible within every continent and decade. Therefore, broader regional findings cannot be generalized to all countries within a region. It also raises the questions about the nature and mechanisms of industrialization. This is explored in the next section. 
Figure 7: Country-specific manufacturing employment share in 2010 s relative to 1990 s

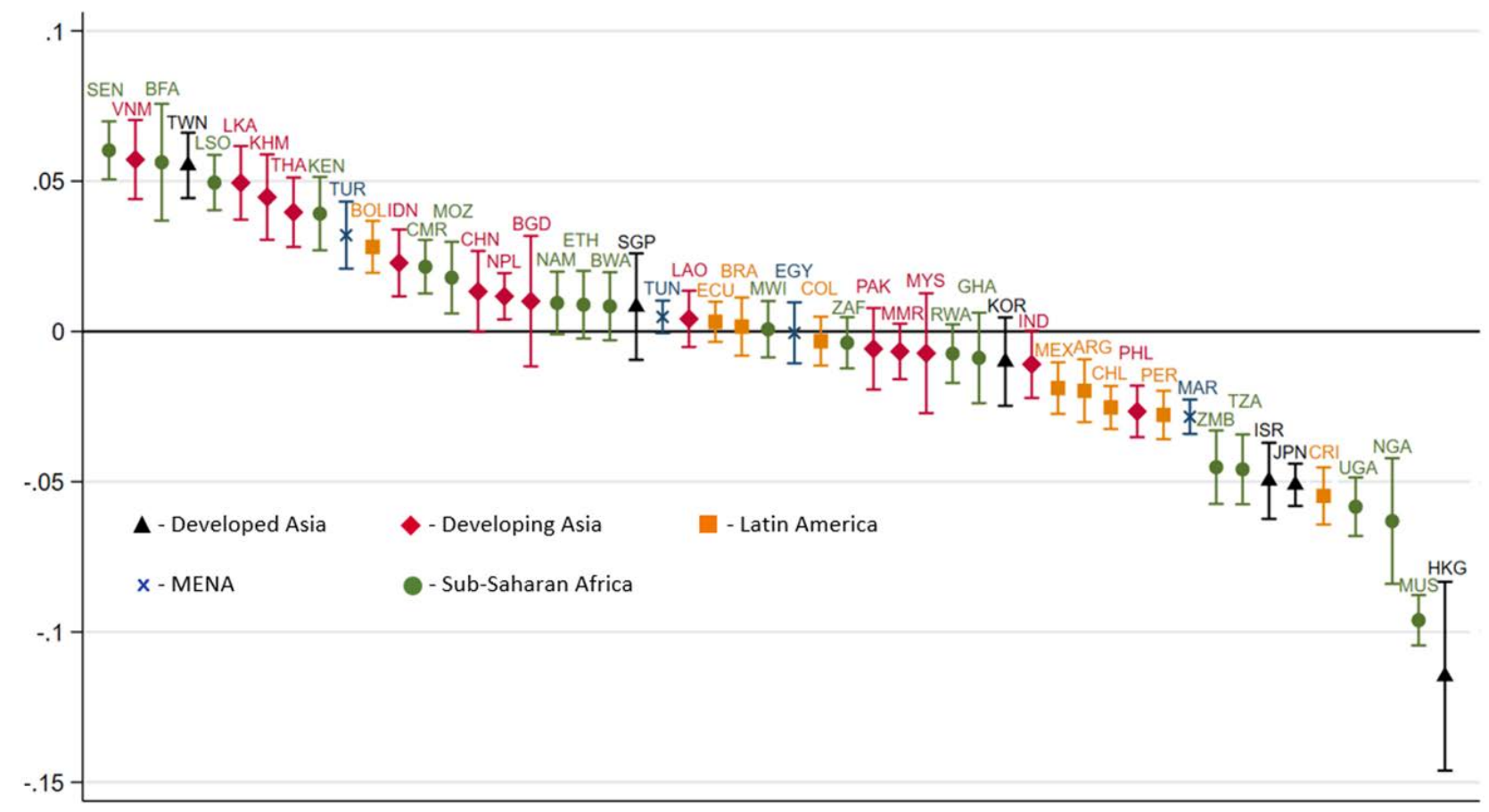

Notes: dependent variable is the manufacturing employment share. Estimated using (2). Marginal effect of the decadal dummy for the 2010 s relative to the 1990 s is shown by country. The $95 \%$ confidence intervals are based on the delta-method Taylor approximation for standard errors of marginal effects. Estimation results are reported in Appendix B Table B2.

Source: authors' calculations.

\section{$7 \quad$ Exploring the nature and mechanisms of industrialization}

So far, we have documented positive industrial trends in various countries, mainly across developing Asia and sub-Saharan Africa. What is the nature of this manufacturing expansion? In subsection 7.1 we start our exploration by splitting manufacturing activity into that covered and not covered by industrial surveys. Typically, industrial surveys cover firms above an employment size threshold. Hence, the split informs whether changes at small unregistered or registered firms relate to observed industrialization trends. In subsection 7.2 we split our country sample into manufactures exporters and non-manufactures exporters to explore whether industrialization is related to an expansion of domestic or foreign demand.

\subsection{Distinguishing between registered and unregistered firms}

Various scholars suggest that industrialization in Africa relates to the expansion of small-scale manufacturing firms (Diao et al. 2021; Mensah 2020). As Lewis (1979) noted, such an expansion of small-scale activity in manufacturing is an important part of the development process. Indeed, small firms may meet domestic demand and provide employment in the process.

This subsection uses the 2-digit manufacturing dataset to distinguish between registered and unregistered firms. Typically, only firms that meet the minimum size or registration criteria are included in official surveys (see Section 2). We will refer to firms included in industrial surveys as registered firms. For each country-year, total MVA and employment of registered firms is subtracted from manufacturing output and employment in the ETD. The residual is defined as 
output and employment of unregistered small firms. The harmonization principles in constructing the ETD and the 2-digit manufacturing data lead us to assume that we roughly capture trends for unregistered firms. We cannot infer whether traditional or modern techniques are used; this likely differs across unregistered firms (Diao and McMillan 2018).

Table 6 reports results from estimating (1), where the dependent variable is the manufacturing employment share in either unregistered (columns 1-3) or registered firms (columns 4-6). ${ }^{19}$ Conditional on income and demographic trends, the change in the manufacturing employment share for the 2010s is positive yet insignificant for registered firms in developing Asia and Latin America (see columns 4 and 5). We also do not find a significant pattern for small unregistered firms in developing Asia and Latin America. For developing Asia, results suggest that both small and large firms contribute to industrialization. In some countries, such as Viet Nam, structural change is found to be related to an expansion of jobs at registered firms (McCaig and Pavcnik 2018). In other developing Asia countries such as India, jobs might mainly be created at small firms (Akcigit et al. 2021).

Table 6: Regressions, manufacturing employment share, registered and unregistered firms

\begin{tabular}{|c|c|c|c|c|c|c|}
\hline & \multicolumn{3}{|c|}{ Unregistered firms } & \multicolumn{3}{|c|}{ Registered firms } \\
\hline & $\begin{array}{l}\frac{0}{5} \\
\frac{0}{0} \\
\frac{0}{0} \\
\frac{0}{0} \\
\frac{0}{0}\end{array}$ & 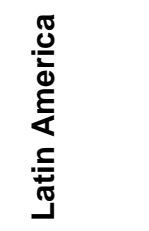 & 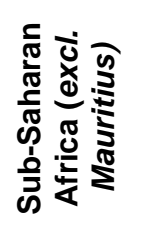 & 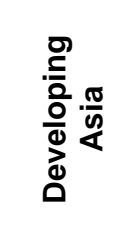 & 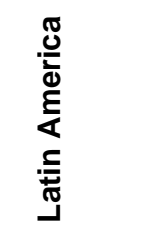 & 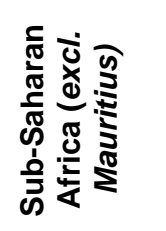 \\
\hline & (1) & (2) & (3) & (4) & (5) & (6) \\
\hline \multirow[t]{2}{*}{ In population } & -0.049 & $0.451^{\star \star \star}$ & -0.064 & 0.055 & $-1.047^{\star \star \star}$ & $0.074^{\star *}$ \\
\hline & $(0.104)$ & $(0.136)$ & $(0.105)$ & $(0.109)$ & (0.090) & $(0.036)$ \\
\hline \multirow[t]{2}{*}{ In population squared } & 0.001 & $-0.011^{\star *}$ & 0.004 & -0.004 & $0.029 * * *$ & $-0.002^{\star *}$ \\
\hline & $(0.003)$ & $(0.004)$ & $(0.003)$ & $(0.003)$ & (0.003) & $(0.001)$ \\
\hline \multirow[t]{2}{*}{ In GDP per capita } & $0.174^{\star \star \star}$ & -0.136 & -0.069 & 0.051 & $1.101^{\star \star *}$ & $0.140^{\star \star \star}$ \\
\hline & $(0.051)$ & $(0.155)$ & $(0.052)$ & $(0.045)$ & $(0.083)$ & $(0.022)$ \\
\hline \multirow[t]{2}{*}{ In GDP per capita squared } & $-0.011^{\star * \star}$ & 0.002 & 0.001 & -0.000 & $-0.058^{\star \star \star}$ & $-0.009 * \star \star *$ \\
\hline & $(0.003)$ & $(0.008)$ & $(0.003)$ & $(0.003)$ & $(0.004)$ & $(0.001)$ \\
\hline \multirow[t]{2}{*}{ 2000s } & 0.006 & $-0.012^{\star \star \star}$ & -0.001 & -0.004 & 0.001 & -0.001 \\
\hline & $(0.004)$ & (0.005) & $(0.003)$ & $(0.004)$ & $(0.003)$ & $(0.001)$ \\
\hline \multirow[t]{2}{*}{ 2010s } & 0.004 & -0.011 & $0.011^{\star *}$ & 0.003 & 0.003 & $-0.004^{\star \star}$ \\
\hline & $(0.006)$ & $(0.007)$ & $(0.005)$ & $(0.006)$ & $(0.004)$ & $(0.002)$ \\
\hline Country-fixed effects & Yes & Yes & Yes & Yes & Yes & Yes \\
\hline Countries & 10 & 9 & 12 & 10 & 9 & 12 \\
\hline Observations & 281 & 261 & 341 & 281 & 261 & 341 \\
\hline $\mathrm{R}^{2}$ & 0.754 & 0.820 & 0.846 & 0.920 & 0.895 & 0.956 \\
\hline
\end{tabular}

Note: dependent variable is the manufacturing employment share. Regressions are estimated using (1). Robust standard errors in parentheses. Columns (1)-(3) show the results for small firms, columns (4)-(6) for registered firms. ${ }^{*} p<0.10,{ }^{* *} p<0.05,{ }^{* \star *} p<0.01$.

Source: authors' calculations.

\footnotetext{
${ }^{19}$ In comparison with the baseline results given in Section 5 , fewer countries are included in this subsection because country coverage is smaller in the 2-digit manufacturing dataset (see Appendix A Table A1).
} 
In sub-Saharan Africa, the 2010s dummy is significantly negative for registered firms (see column 6) ${ }^{20}$ In contrast, the results in column (3) suggest that there has been a significant employment expansion in unregistered firms in Africa in the 2010s. This suggests that employment industrialization in sub-Saharan Africa is driven by small firms.

Table 7 presents the results for real MVA. For developing Asia, we again find that industrialization does not appear predominantly driven by either small or registered firms. For Latin America, we find significant positive (negative) output industrialization for small (registered) firms. In combination with the results for employment industrialization, this suggests that productivity growth was higher in smaller than larger firms. The opposite is observed in sub-Saharan Africa. Indeed, employment industrialization is observed in small unregistered firms, but its output share declines (column 3 of Table 7). For registered firms, the employment share declines, but the output share increases. This points to productivity improvements among firms included in the industrial surveys (Rodrik 2013). These results also align with those of Diao et al. (2021), who observe productivity growth but no increase in employment by large firms in Ethiopia and Tanzania. Smaller firms absorb workers and do not experience much productivity growth. The findings presented here suggest that this pattern holds more widely across sub-Saharan Africa.

Table 7: Regressions, real manufacturing value added, small and large firms

\section{Small firms}

In population

In population squared

In GDP per capita

In GDP per capita squared

2000 s

2010s

Country fixed effects

Countries

Observations

$\mathrm{R}^{2}$

일

(1)

(2)

$1.938^{\star \star \star}$

$(0.284)$

$-0.051^{\star \star \star}$

(0.008)

$0.333^{\star \star}$

(0.151)

$-0.023^{\star *}$

(0.009)

$0.032^{\text {** }}$

(0.015)

0.007

(0.020)

Yes

10

280

0.472
0.602

(0.418)

$-0.028^{\star *}$

(0.013)

0.174

(0.277)

$-0.008$

(0.015)

$0.018^{\text {* }}$

(0.009)

0.038 ***

(0.014)

Yes

9
261
0.866

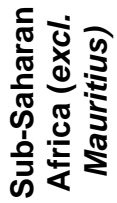

(3)

$0.358^{\star \star \star}$

(0.128)

$-0.009^{* *}$

(0.004)

0.002

(0.084)

$-0.005$

(0.005)

-0.010 *

(0.006)

$-0.021^{\text {** }}$

(0.010)

Yes

12
341
0.846

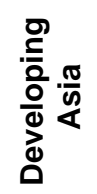

(4)

$-0.941^{\star * *}$

(0.259)

$0.022^{\star \star \star}$

(0.007)

0.060

(0.135)

0.003

(0.008)

$-0.033^{\star *}$

(0.014)

$-0.020$

(0.018)

Yes

10
280
0.679

Large firms
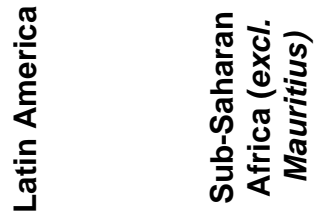

(5)

(6)

$-1.388^{\star \star \star}$

(0.451)

$0.051^{\text {*** }}$

(0.014)

$0.573^{\text {** }}$

(0.280)

$-0.034^{\text {** }}$

(0.015)

$-0.016^{*}$

(0.009)

$-0.045^{\star \star \star}$

(0.014)

Yes

9

261

0.618

$0.296^{\star \star *}$

(0.101)

$-0.011^{\star \star *}$

(0.003)

$0.274^{\star \star *}$

(0.067)

$-0.013^{\star \star \star}$

(0.004)

0.007

(0.005)

$0.022^{\star \star \star}$

(0.008)

Yes

12

341

0.701

Notes: dependent variable is the manufacturing employment share. Regressions are estimated using (1). Robust standard errors in parentheses. Columns (1)-(3) show the results for small firms. Columns (4)-(6) for large firms. ${ }^{*} p<0.10,{ }^{* *} p<0.05,{ }^{* \star *} p<0.01$.

Source: authors' calculations.

\footnotetext{
${ }^{20}$ Appendix B Table B4 shows that employment de-industrialization is observed in registered firms across various industries, including food processing and textile manufacturing, in sub-Saharan Africa.
} 


\subsection{Manufactures exporters versus non-manufactures exporters}

Next, we explore whether industrialization relates to comparative advantage. Wood (2017) documents a positive (negative) relation between land-scarce (land-abundant) countries and labour-intensive manufacturing exports. Hence, factor endowments appear related to sectoral specialization in international trade.

We follow Rodrik (2016) and classify a country as a manufactures (non-manufactures) exporter if its share of manufactures in exports is more (less) than 75 per cent. In a second grouping, we classify a country as a manufactures exporter if its share of manufactures in exports exceeds the corresponding import share. We compute the average manufacturing export and import shares from the BACI database from 1995-2018. Manufactures exports are defined broadly, including processed food products and refined petroleum, to match the sectoral output and employment data. We use WDI as a cross-check and classify several countries not covered in the BACI. ${ }^{21}$

Table 8 reports the results when making these splits. The results for the 2000s are partly in line with those in Rodrik (2016), namely that changes in the real manufacturing output share are positive and significant for manufactures exporters. Yet, for the 2000s it is not clear whether employment losses differ between manufactures exporters and non-manufactures exporters. That depends on the classification used. The findings for the 2010s suggest that countries with a comparative advantage in manufactures experienced employment de-industrialization, whereas non-manufactures exporters did not.

The higher exposure of manufacturing firms to international competition incentivizes them to improve productivity (e.g. Goldberg and Pavcnik 2007; Pavcnik 2002). If productivity increases, fewer workers are needed to produce the same output. Globalization has intensified and manufactures trade has become more competitive, which might explain why employment deindustrialization has become significant for manufactures exporters.

Manufacturing firms in sub-Saharan African might have increased production of lower quality goods to meet rising demand by domestic consumers. If so, they are less exposed to international competition. That might explain their low manufacturing productivity growth. The industrialization in non-manufactures exporters could thus be driven by domestic rather than foreign demand. An increase in agricultural income, public expenditures, and external transfers may have expanded the market for (lower quality) manufactured goods (Diao et al. 2019, 2021). If so, the manufacturing activities are not traded internationally but rather meet rising domestic demand. We intend to investigate this further in a later version of the paper.

\footnotetext{
${ }^{21}$ Botswana, Lesotho, Namibia, and South Africa are not in the BACI database. Chinese Taipei is in neither the BACI nor the WDI database, but trade data from the NSI indicates that it is a manufactures exporter.
} 
Table 8: Results by specialization in manufacturing

\begin{tabular}{|c|c|c|c|c|c|c|c|c|}
\hline & \multicolumn{4}{|c|}{ Non-manufactures exporters } & \multicolumn{4}{|c|}{ Manufactures exporters } \\
\hline & \multicolumn{2}{|c|}{$\begin{array}{l}\text { Manufactures exports } \\
<75 \%\end{array}$} & \multicolumn{2}{|c|}{$\begin{array}{l}\text { Share of manufactures } \\
\text { exports <share of } \\
\text { manufactures imports }\end{array}$} & \multicolumn{2}{|c|}{$\begin{array}{c}\text { Manufactures exports } \\
>75 \%\end{array}$} & \multicolumn{2}{|c|}{$\begin{array}{l}\text { Share of manufactures } \\
\text { exports >share of } \\
\text { manufactures imports }\end{array}$} \\
\hline & EMP & RMVA & EMP & RMVA & EMP & RMVA & EMP & RMVA \\
\hline \multirow[t]{2}{*}{ In population } & 0.042 & $-0.237^{\star \star}$ & $-0.203^{\star \star \star}$ & $-0.309 * * \star$ & $-0.369 * \star *$ & $-0.493^{\star \star *}$ & $-0.174^{\star \star}$ & $-0.377^{\star \star \star}$ \\
\hline & $(0.051)$ & $(0.095)$ & $(0.078)$ & $(0.113)$ & $(0.076)$ & $(0.087)$ & $(0.071)$ & $(0.092)$ \\
\hline \multirow[t]{2}{*}{ In population squared } & -0.000 & $0.007^{\star \star}$ & $0.007^{\star \star \star}$ & $0.009 * *$ & $0.009 * * \star$ & $0.012^{\star \star \star}$ & 0.003 & $0.009 * \star \star$ \\
\hline & $(0.002)$ & $(0.003)$ & $(0.002)$ & $(0.004)$ & $(0.002)$ & $(0.002)$ & $(0.002)$ & $(0.003)$ \\
\hline \multirow[t]{2}{*}{ In GDP per capita } & $0.232^{\star \star \star}$ & $0.110 * \star \star$ & $0.400 * \star \star$ & $0.101^{\star \star \star}$ & $0.537^{\star \star \star}$ & 0.058 & $0.480^{\star \star \star}$ & -0.039 \\
\hline & $(0.022)$ & $(0.040)$ & $(0.036)$ & $(0.039)$ & $(0.041)$ & $(0.041)$ & $(0.037)$ & $(0.050)$ \\
\hline \multirow[t]{2}{*}{ In GDP per capita squared } & $-0.015^{\star \star \star}$ & $-0.007^{\star \star \star}$ & $-0.025^{\star \star \star}$ & $-0.006^{\star \star \star}$ & $-0.028^{\star \star \star}$ & 0.001 & $-0.025^{\star \star \star}$ & $0.005^{\star}$ \\
\hline & $(0.001)$ & $(0.002)$ & $(0.002)$ & $(0.002)$ & $(0.002)$ & $(0.002)$ & $(0.002)$ & $(0.003)$ \\
\hline \multirow[t]{2}{*}{$2000 s$} & -0.002 & 0.003 & $-0.008^{\star \star \star}$ & 0.004 & $-0.016^{* * *}$ & $0.005^{*}$ & $-0.006^{* *}$ & $0.007 * *$ \\
\hline & $(0.002)$ & $(0.003)$ & $(0.002)$ & $(0.003)$ & $(0.003)$ & $(0.003)$ & $(0.003)$ & $(0.003)$ \\
\hline \multirow[t]{2}{*}{ 2010s } & 0.004 & 0.002 & -0.003 & 0.001 & $-0.025^{\star \star \star}$ & $-0.007^{*}$ & $-0.011^{\star \star}$ & -0.003 \\
\hline & $(0.003)$ & $(0.005)$ & $(0.004)$ & $(0.005)$ & $(0.005)$ & $(0.004)$ & $(0.005)$ & $(0.005)$ \\
\hline Countries & 29 & 29 & 31 & 31 & 22 & 22 & 20 & 20 \\
\hline Observations & 841 & 841 & 899 & 899 & 638 & 638 & 580 & 580 \\
\hline $\mathrm{R}^{2}$ & 0.890 & 0.848 & 0.865 & 0.861 & 0.885 & 0.902 & 0.920 & 0.873 \\
\hline
\end{tabular}

Note: dependent variable is the manufacturing employment share. Regressions are estimated using (1). Countries in the sample where manufactures exports are $>75 \%$ are Bangladesh, Botswana, Cambodia, China, Costa Rica, Hong Kong, Israel, Japan, Lesotho, Malaysia, Mauritius, Mexico, Morocco, Pakistan, Philippines, Singapore, South Korea, Taiwan, Thailand, Tunisia, Turkey, and Viet Nam. Countries in the sample where manufactures exports are >manufactures imports are Bangladesh, Botswana,

Cambodia, China, India, Israel, Japan, Lesotho, Mauritius, Morocco, Nepal, Pakistan, Philippines, Singapore, Sri Lanka, South Korea, Taiwan, Thailand, Tunisia, and Turkey. Robust standard errors in parentheses. ${ }^{*} p<0.10,{ }^{\star *} p<0.05,{ }^{\star \star *} p<0.01$

Source: authors' construction. 
Historically, industrialization has been a necessary condition for rising levels of economic development and poverty reduction (Szirmai 2012). This paper analyses industrialization trends for a large set of developing countries based on the newly constructed GGDC/UNU-WIDER Economic Transformation Database. We confirm that de-industrialization was widespread until the early 2000s. But the trend reversed thereafter. We document significant employment industrialization for many countries in Asia and sub-Saharan Africa. For sub-Saharan Africa, the regression estimates suggest a recovery of manufacturing by more than half the downward shift observed during the period 1960-2010. This suggests that it was premature to conclude that the developing world is de-industrializing.

The results carry important implications about opportunities for growth and development. Yet, the findings also create new questions. Why has there been a reversal in the industrialization trend? Will manufacturing continue to expand and will it relate to sustained productivity and income growth? Does re-industrialization imply that manufacturing can still be important for economic development?

Manufacturing can contribute to reductions in poverty and rising living standards, but that depends on the nature of industrialization. The classic historical development pattern relates growth and poverty reduction to the expansion of modern manufacturing activities (Lewis 1954; Pack and Nelson 1999). Modern manufacturing activities are characterized by their higher technology content, economies of scale, and international competitiveness.

We explore whether industrialization relates to an expansion of registered or unregistered manufacturing firms. We use industrial surveys and find that in particular small unregistered manufacturing firms are contributing to the manufacturing renaissance in sub-Saharan Africa. We also distinguish between manufactures exporters and non-manufactures exporters and find that domestic rather than foreign demand appears to be driving the manufacturing renaissance. We aim to extend this exploration in a later version of this paper.

\section{References}

Africa Headline News (2017). 'Rwanda: Country's Unemployment Rate Rises Sharply to 16.7 Pct Due to New Definition.' Xinbua, 10 October.

Akcigit, U., H. Alp, and M. Peters (2021). 'Lack of Selection and Limits to Delegation: Firm Dynamics in Developing Countries'. American Economic Review, 111(1): 231-75. https://doi.org/10.1257/ aer.20180555

Atiola, M., P. Loungani, M. Marquis, and C. Papageorgiou (2020). 'Rethinking Development Policy: What Remains of Structural Transformation?’.World Development, 128(April): 104834. https://doi.org/ 10.1016/j.worlddev.2019.104834

Bolt, J., and J.L. van Zanden (2020. 'Maddison Style Estimates of the Evolution of the World Economy. A New 2020 Update’. Maddison Project Working Paper 15. Groningen: University of Groningen.

Bosworth, B., and S.M. Collins (2008). 'Accounting for Growth: Comparing China and India'. Journal of Economic Perspectives, 22(1): 45-66. https://doi.org/10.1257/jep.22.1.45

Chenery, H.B. (1960). 'Patterns of Industrial Growth'. American Economic Review, 50(4): 624-54.

Comin, D.A., D. Lashkari, and M. Mestieri (2021). 'Structural Change with Long-run Income and Price Effects'. Econometrica, 89(1): 311-74. https://doi.org/10.3982/ECTA16317 
Danquah, M., S. Schotte, and K. Sen (2019). 'Informal Work in Sub-Saharan Africa: Dead End or Steppingstone?'. WIDER Working Paper 2019/107. Helsinki: UNU-WIDER. https://doi.org/10.35188/UNU-WIDER/2019/743-9

de Vries, G., L. Arfelt, D. Drees, M. Godemann, C. Hamilton, B. Jessen-Thiessen, A. Ihsan Kaya, H. Kruse, E. Mensah, and P. Woltjer (2021). 'The Economic Transformation Database (ETD): Content, Sources, and Methods'. WIDER Technical Note 2021/2. Helsinki: UNU-WIDER. https://doi.org/10.35188/UNU-WIDER/WTNN/2021-2

Diao, X., and M. McMillan (2018). 'Toward an Understanding of Economic Growth in Africa: A Reinterpretation of the Lewis Model'. World Development, 109: 511-22. https://doi.org/10.1016/ j.worlddev.2016.12.008

Diao, X., K. Harttgen, and M. McMillan (2017). 'The Changing Structure of Africa's Economies'. World Bank Economic Review, 31(2): 412-33. https://doi.org/10.1093/wber/lhw070

Diao X., M. McMillan, and D. Rodrik (2019). 'The Recent Growth Boom in Developing Economies: a Structural-Change Perspective'. In The Palgrave Handbook of Development Economics. Basingstoke: Palgrave Macmillan. https://doi.org/10.1007/978-3-030-14000-7_9

Diao, X., M. Ellis, M. McMillan, and D. Rodrik (2021). 'Africa's Manufacturing Puzzle: Evidence from Tanzanian and Ethiopian Firms’. NBER Working Paper 28344. Cambridge, MA: National Bureau of Economic Research. https://doi.org/10.3386/w28344

Felipe, J., A. Mehta, and C. Rhee (2014). 'Manufacturing matters... But It's the Jobs that Count'. Asian Development Bank Economics Working Paper 420. Mandaluyong: Asian Development Bank.

Gaddis, I., G. Oseni, A. Palacios-Lopez, and J. Pieters (2020). 'Who Is Employed? Evidence from SubSaharan Africa on Redefining Employment'. World Bank Policy Research Working Paper 9370. Washington, DC: The World Bank. https://doi.org/10.1596/1813-9450-9370

Gaulier, G., and S. Zignago (2010). 'BACI: International Trade Database at the Product-Level. The 1994 2007 Version'. CEPII Working Paper 2010-23. Paris: Centre d'Études Prospectives et d'Informations Internationales. https:// doi.org/10.2139/ssrn.1994500

Goldberg, P.K., and N. Pavcnik (2007). 'Distributional Effects of Globalization in Developing Countries'. Journal of Economic Literature, 45(1): 39-82. https://doi.org/10.1257/jel.45.1.39

Gollin, D., D. Lagakos, and M.E. Waugh (2014). 'The Agricultural Productivity Gap'. Quarterly Journal of Economics, 129(2): 939-93. https:/ / doi.org/10.1093/qje/qjt056

Haraguchi, N., C.F.C. Cheng, and E. Smeets (2017). 'The Importance of Manufacturing in Economic Development: Has This Changed?' World Development, 93: 293-315. https://doi.org/10.1016/ j.worlddev.2016.12.013

Herrendorf, B., R. Rogerson, and A. Valentinyi (2014). 'Growth and Structural Transformation'. In Handbook of Economic Growth, Vol. 2, pp. 855-941. Amsterdam: Elsevier. https://doi.org/ 10.1016/B978-0-444-53540-5.00006-9

ICLS (2013). 'Resolution Concerning Statistics of Work, Employment, and Labor Underutilization.' Delivered at 19th International Conference of Labour Statisticians. Geneva: International Conference of Labour Statisticians.

IMF (2020). World Economic Outlook: The Great Lockdown. Washington, DC: International Monetary Fund.

Klasen, S. (2019). 'What Explains Uneven Female Labor Force Participation Levels and Trends in Developing Countries?'. The World Bank Research Observer, 34(2), 161-97. https://doi.org/10.1093/ wbro/lkz005

Lewis, W.A. (1954). 'Economic Development with Unlimited Supplies of Labour'. The Manchester School, 22: 139-91. https://doi.org/10.1111/j.1467-9957.1954.tb00021.x

Lewis, W.A. (1979). 'The Dual Economy Revisited'. The Manchester School, 47(3): 211-29. https://doi.org/ 10.1111/j.1467-9957.1979.tb00625.x 
Maddison, A. (2009). 'Statistics on World Population, GDP and Per Capita GDP, 1-2008 AD'. Available at: https://www.rug.nl/ggdc/historicaldevelopment/maddison/releases/maddison-database-2010 (accessed 1 February 2021).

McCaig, B., and N. Pavcnik (2018). 'Export Markets and Labor Allocation in a Low-income Country'. American Economic Review, 108(7): 1899-941. https://doi.org/10.1257/aer.20141096

McCullough, E.B. (2017). 'Labor Productivity and Employment Gaps in Sub-Saharan Africa'. Food Policy, 67: 133-52. https://doi.org/10.1016/j.foodpol.2016.09.013

Mensah, E.B. (2020). 'Is Sub-Saharan Africa Deindustrializing?'. GGDC Research Memorandum 186. Groningen: Groningen Growth and Development Centre, University of Groningen.

Mokyr, J. (1990). The Lever of Riches: Technological Creativity and Economic Progress. Oxford: Oxford University Press.

Nguimkeu, P., and A. Zuefack (2019). 'Manufacturing in Structural Change in Africa'. World Bank Policy Research Working Paper 8992. Washington, DC: The World Bank. https://doi.org/10.1596/18139450-8992

Pack, H., and R.R. Nelson (1999). 'The Asian Miracle and Modern Growth Theory'. The Economic Joumal, 109(July): 416-36. https:// doi.org/10.1596/1813-9450-1881

Pahl, S., and M. Timmer (2019). 'Do Global Value Chains Enhance Economic Upgrading? A Long View'. Journal of Development Studies, 00(00): 1-23.

Palma, J.G. (2005). 'Four Sources of De-Industrialisation and a New Concept of the Dutch-Disease'. In J.A. Ocampo (ed.), Beyond Reforms: Structural Dynamic and Macroeconomic Vulnerability. Stanford, CA: Stanford University Press and the World Bank.

Pavcnik, N. (2002). 'Trade Liberalization, Exit, and Productivity Improvements: Evidence from Chilean Plants'. Review of Economic Studies, 69(1): 245-76. https://doi.org/10.1111/1467-937X.00205

Rodrik, D. (2013). 'Unconditional Convergence in Manufacturing'. The Quarterly Journal of Economics, 128(1): 165-204. https://doi.org/10.1093/qje/qjs047

Rodrik, D. (2016). 'Premature Deindustrialization'. Journal of Economic Growth, 21: 1-33. 'https://doi.org/ 10.1007/s10887-015-9122-3

Schreyer, P. (2002). Computer Price Indices and International Growth and Productivity Comparisons'. Review of Income and Wealth, 48(1): 15-31. https://doi.org/10.1111/1475-4991.00038

Sen, K. (2019). 'Structural Transformation around the World: Patterns and Drivers'. Asian Development Review, 36(2): 1-31. https://doi.org/10.1162/adev_a_00130

Szirmai, A. (2012). 'Industrialisation as an Engine of Growth in Developing Countries, 1950-2005'. Structural Change and Economic Dynamics, 23(4): 406-20. https:// doi.org/10.1016/j.strueco.2011.01.005

Szirmai, A., and B. Verspagen (2015). 'Manufacturing and Economic Growth in Developing Countries, 1950-2005'. Structural Change and Economic Dynamics, 34: 46-59. https://doi.org/10.1016/ j.strueco.2015.06.002

The Economist (2020). 'How Manufacturing Might Take off in Africa'. 13 June. Available at: https://www.economist.com/middle-east-and-africa/2020/06/11/how-manufacturing-might-takeoff-in-africa (accessed 2 February 2021).

United Nations (1993). 'System of National Accounts 1993'. New York: United Nations. Available at: https://unstats.un.org/unsd/nationalaccount/sna1993.asp (accessed 21 January 2021).

United Nations (2008). 'System of National Accounts 2008'. New York: United Nations. Available at: https://unstats.un.org/unsd/nationalaccount/docs/SNA2008.pdf (accessed 21 January 2021).

University of Groningen (2020). 'Maddison Historical Statistics'. Groningen: University of Groningen. Available at: https://www.rug.nl/ggdc/historicaldevelopment/maddison/?lang=en (accessed 2 February 2021). 
Wood, A. (2017). 'Variation in Structural Change around the World, 1985-2015: Patterns, Causes and Implications'. WIDER Working Paper 2017/34. Helsinki: UNU-WIDER. https://doi.org/10.35188/ UNU-WIDER/2017/258-8

World Bank (2020). Global Productivity: Trends, Drivers, and Policies. Washington, DC: World Bank Group.

Zhou, H. (2009). 'Population Growth and Industrialization'. Economic Inquiry, 47(2): 249-65. https://doi.org/10.1111/j.1465-7295.2008.00151.x 


\section{Appendix A: Description of 2-digit manufacturing dataset}

The primary source for constructing the 2-digit manufacturing dataset is the United Nations Industrial Development Organization (UNIDO) Industrial and Statistical Database (UNIDO INDSTATS 2, 2020). When there is no reliable benchmark or consistent series from the UNIDO INDSTATS 2 (INDSTATS), this is complemented by national accounts (NA) or industrial surveys from national statistical institutes (NSI). For example, Nigeria's value added (VA) series from 1997 to 2018 is not available in INDSTATS. To obtain a series for Nigeria, we therefore use detailed industry trends from the rebased NA data. The general approach follows Pahl and Timmer (2019). The guiding principle is to ensure that the data are consistent over time, across variables (employment and VA), and across countries.

In Pahl and Timmer (2019), missing data are treated as follows: First, all negative entries for all variables are set to missing. In the primary data (INDSTATS), zeros could appear when the industry is not sampled in the respective year or when there is no economic activity in that industry. To distinguish between these two, Pahl and Timmer (2019) treat zeros as missing if (i) an industry has a positive value in year 1 , a zero in year 2 , but a positive value in year 3 , on the assumption that the zero in-between is a missing value; or (ii) the industry records zeros at the beginning or end of a time series but grows from 0 per cent to more than 5 per cent of total manufacturing or vice versa, allowing for the possibility that industries emerge and vanish, but only if the change is not beyond 5 per cent of total manufacturing.

Our sample is mainly for developing countries where, apart from light industry (food processing and textile industries), the average share of other sectors is about 5 per cent, so treating zeros as missing if the share in year $\mathrm{t}-1$ or $\mathrm{t}+1$ is less than 5 per cent of total manufacturing would drop most missing observations or sectors. Therefore, we make the treatment of zeros and missing information country- and sector-specific. For example, if the average share of a series of a specific industry is more than 10 per cent, between 5-10 per cent, or below 5 per cent, then we treat zeros as missing if the industry grows from zero to 5 per cent, 1 per cent, or 0.2 per cent of total manufacturing, respectively. Finally, observations are treated as missing if there is a positive value for other variables. For example, if there is a positive value for VA but the employment variable is zero, we treat the zeros as missing information.

We fill in missing data using interpolation, extrapolation, and retropolation as follows. We use VA in basic prices as a benchmark for VA series, then interpolate between benchmark years, retropolate from the last benchmark, or extrapolate from the latest benchmark using growth trend from NA data, if detailed industry series are available, or industrial production survey data. If there are no detailed industry data from NA or industrial production surveys, we use growth trends of total manufacturing VA from INDSTATS. For employment series, we use number of employees as the benchmark, then interpolate, extrapolate, and retropolate using the growth trend of total manufacturing labour productivity. We express VA in constant prices following Schreyer (2002), where the domestic industry deflator is the US industry deflator adjusted for domestic inflation in the manufacturing sector. The data cover 40 developing countries that are also in the ETD (Table A1). The data are disaggregated into 2-digit manufacturing industries (Table A2). This results in data for VA (current and constant prices) and employment at the 2-digit ISIC rev. 4 level for 19902018. 
Table A1: Country coverage 2-digit manufacturing dataset

\section{ETD countries covered}

Developing Asia (10)

Advanced Asia (4)

Latin America (9)

Middle East and North Africa (4)

Sub-Saharan Africa (13)

Time period (annual)

Variables
Bangladesh, China, India, Indonesia, Malaysia, Myanmar, Philippines, Sri Lanka, Thailand, Viet Nam

Israel, Japan, Korea (Rep. of), Singapore

Argentina, Bolivia, Brazil, Chile, Colombia, Costa Rica, Ecuador, Mexico, Peru

Egypt, Morocco, Tunisia, Turkey

Botswana, Cameroon, Ethiopia, Ghana, Kenya, Malawi, Mauritius, Namibia, Nigeria, Senegal, South Africa, Tanzania, Uganda

ETD countries not included in 2-digit manufacturing dataset Burkina Faso, Cambodia, Chinese Taipei, Hong Kong (China), Laos, Lesotho, Mozambique, Pakistan, Rwanda, Zambia

1990-2018

Gross VA at constant (2015) prices (national currency in millions)

Gross VA at current prices (national currency in millions)

Number of employees (in thousands)

Source: authors' construction based on UNIDO INDSTATS 2, 2020; national accounts; industry surveys; establishment surveys.

Table A2: 2-digit ISIC revision 4 manufacturing sectors

\begin{tabular}{|c|c|c|}
\hline ISIC rev. 4 & ETD & ISIC rev. 4 description \\
\hline C10-C12 & FOOD & Manufacture of food products, beverages, and tobacco products \\
\hline C13-C15 & TEXT & Manufacture of textiles, clothing, and leather products \\
\hline C16 & WOOD & $\begin{array}{l}\text { Manufacture of wood and of products of wood and cork, except furniture; } \\
\text { manufacture of articles of straw and plaiting materials }\end{array}$ \\
\hline C17 & PAPER & Manufacture of paper and paper products \\
\hline C18 & PRINT & Printing and reproduction of recorded media \\
\hline C19 & PETRO & Manufacture of coke and refined petroleum products \\
\hline C20-C21 & $\begin{array}{l}\text { CHEMICALS \& } \\
\text { PHARMA }\end{array}$ & $\begin{array}{l}\text { Manufacture of chemicals and chemical products; } \\
\text { Manufacture of basic pharmaceutical products and pharmaceutical preparations }\end{array}$ \\
\hline $\mathrm{C} 22$ & RUBBER & Manufacture of rubber and plastic products \\
\hline C23 & MINERAL & Manufacture of other non-metallic mineral products \\
\hline $\mathrm{C} 24$ & BAS METAL & Manufacture of basic metals \\
\hline C25 & FAB METAL & Manufacture of fabricated metal products, except machinery and equipment \\
\hline C26 & COMPUTER & Manufacture of computer, electronic, and optical products \\
\hline C27 & ELECTRICAL & Manufacture of electrical equipment \\
\hline C28 & MACHINERY & Manufacture of machinery and equipment n.e.c. \\
\hline C29 & MOTOR & Manufacture of motor vehicles, trailers, and semi-trailers \\
\hline C30 & OTH TRANS & Manufacture of other transport equipment \\
\hline C31-C33 & FURNI; OTH. & $\begin{array}{l}\text { Manufacture of furniture; Other manufacturing; Repair and installation of } \\
\text { machinery and equipment }\end{array}$ \\
\hline Cf & TOTAL & Total manufacturing \\
\hline
\end{tabular}

Source: authors' construction. 


\section{Appendix B: Regressions and trends}

Table B1: Baseline regressions, manufacturing value added share in current prices

\begin{tabular}{|c|c|c|c|c|c|c|}
\hline & $\begin{array}{c}\text { All } \\
\text { countries }\end{array}$ & $\begin{array}{l}\text { Advanced } \\
\text { Asia }\end{array}$ & $\begin{array}{l}\text { Developing } \\
\text { Asia }\end{array}$ & $\begin{array}{l}\text { Latin } \\
\text { America }\end{array}$ & $\begin{array}{c}\text { Sub- } \\
\text { Saharan } \\
\text { Africa }\end{array}$ & $\begin{array}{c}\text { Sub- } \\
\text { Saharan } \\
\text { Africa excl. } \\
\text { Mauritius }\end{array}$ \\
\hline & (1) & (2) & (3) & (4) & (5) & (6) \\
\hline \multirow[t]{2}{*}{ In population } & 0.076 & 0.623 & $0.550^{\star \star \star}$ & $-0.784^{\star \star \star}$ & $0.489 * \star \star$ & $0.519^{\star \star \star}$ \\
\hline & $(0.057)$ & $(0.783)$ & $(0.098)$ & $(0.121)$ & $(0.093)$ & $(0.092)$ \\
\hline \multirow[t]{2}{*}{ In population squared } & $-0.005^{\star \star \star}$ & -0.024 & $-0.016^{\star \star \star}$ & $0.019 * \star \star$ & $-0.015^{\star \star \star}$ & $-0.016^{\star \star \star}$ \\
\hline & $(0.002)$ & $(0.026)$ & $(0.003)$ & $(0.004)$ & $(0.003)$ & $(0.003)$ \\
\hline \multirow[t]{2}{*}{ In GDP per capita } & $0.249^{* \star \star}$ & $1.148^{\star \star}$ & $0.426^{\star \star \star}$ & $0.422^{\star \star \star}$ & $0.204^{\star \star \star}$ & $0.169^{\star \star \star}$ \\
\hline & $(0.028)$ & $(0.513)$ & $(0.043)$ & $(0.116)$ & $(0.052)$ & $(0.052)$ \\
\hline \multirow[t]{2}{*}{ In GDP per capita squared } & $-0.013^{\star \star \star}$ & $-0.053^{* *}$ & $-0.023^{\star \star \star}$ & $-0.025^{\star \star \star}$ & $-0.013^{\star \star \star}$ & $-0.011^{\star \star \star}$ \\
\hline & $(0.002)$ & $(0.024)$ & $(0.003)$ & $(0.006)$ & $(0.003)$ & $(0.003)$ \\
\hline \multirow[t]{2}{*}{$2000 s$} & -0.000 & $-0.014^{\star \star \star}$ & 0.004 & 0.007 & $-0.010^{\star \star \star}$ & $-0.008^{\star \star \star}$ \\
\hline & $(0.002)$ & $(0.005)$ & $(0.004)$ & $(0.005)$ & $(0.003)$ & $(0.003)$ \\
\hline \multirow[t]{2}{*}{$2010 s$} & $-0.014^{\star \star \star}$ & $-0.016^{\star \star \star}$ & $-0.015^{\star \star}$ & 0.005 & $-0.031^{\star \star \star}$ & $-0.027^{\star \star \star}$ \\
\hline & $(0.003)$ & $(0.006)$ & $(0.007)$ & $(0.007)$ & $(0.005)$ & $(0.005)$ \\
\hline Country-fixed effects & Yes & Yes & Yes & Yes & Yes & Yes \\
\hline Countries & 51 & 6 & 14 & 9 & 18 & 17 \\
\hline Observations & 1,479 & 174 & 406 & 261 & 522 & 493 \\
\hline
\end{tabular}

Notes dependent variable is the manufacturing value added share in current prices. Regressions estimated using equation (1). Robust standard errors in parentheses. See Table 1 for the country groupings. Developing Asia corresponds to the IMF (2020) country grouping 'Emerging and Developing Asia'. The results for the six Asian high-income economies and for the four countries from the MENA region are not reported separately but are included in the full sample, and the former are included in all Asian economies in column (2). ${ }^{*} p<0.10,{ }^{\star *} p<0.05$, *** $p<0.01$.

Source: authors' calculations based on ETD and University of Groningen (2020). 
Table B2: Regional and country-specific industrialization trends, manufacturing employment

\begin{tabular}{|c|c|c|c|c|c|c|c|}
\hline Countries by region & $2010 s \times C$ & 2010s & $\begin{array}{l}\text { Marginal effect } \\
\text { (net shift) }\end{array}$ & $2000 s \times C$ & 2000s & $\begin{array}{l}\text { Marginal effect } \\
\text { (net shift) }\end{array}$ & $\mathbf{R}^{2}$ \\
\hline Asia & $0.008^{* *}(0.003)$ & $-0.006^{*}(0.003)$ & $0.002(0.004)$ & $-0.001(0.003)$ & $-0.005^{\star * \star}(0.002)$ & $-0.006^{* *}(0.003)$ & 0.91 \\
\hline Advanced Asia & $-0.039 * * *(0.006)$ & $0.002(0.003)$ & $-0.037^{* * *}(0.006)$ & $-0.030 * * *(0.005)$ & $-0.001(0.002)$ & $-0.032^{* * *}(0.000)$ & 0.91 \\
\hline Taiwan & $0.059^{\star \star \star}(0.005)$ & $-0.004(0.003)$ & $0.055^{\star \star \star}(0.006)$ & $0.035^{\star \star \star}(0.005)$ & $-0.006^{\star \star \star}(0.002)$ & $0.029^{\star \star \star}(0.005)$ & 0.91 \\
\hline Singapore & $0.010(0.008)$ & $-0.002(0.003)$ & $0.008(0.009)$ & $0.011(0.007)$ & $-0.005^{\star \star \star}(0.002)$ & $0.006(0.008)$ & 0.91 \\
\hline South Korea & $-0.007(0.007)$ & $-0.003(0.003)$ & $-0.010(0.007)$ & $-0.016^{\star *}(0.007)$ & $-0.005^{\star \star \star}(0.002)$ & $-0.021^{\star \star \star}(0.007)$ & 0.91 \\
\hline Israel & $-0.048^{\star \star \star}(0.006)$ & $-0.002(0.003)$ & $-0.050^{\star * *}(0.006)$ & $-0.038^{\star \star *}(0.006)$ & $-0.005^{\star \star \star}(0.002)$ & $-0.043^{\star \star \star}(0.006)$ & 0.91 \\
\hline Japan & $-0.053^{\star \star \star}(0.004)$ & $0.002(0.003)$ & $-0.051^{* * *}(0.004)$ & $-0.030^{\star * *}(0.005)$ & $-0.003(0.002)$ & $-0.033^{\star \star *}(0.004)$ & 0.91 \\
\hline Hong Kong & $-0.117^{\star \star \star}(0.016)$ & $0.002(0.003)$ & $-0.115^{\star \star \star}(0.016)$ & $-0.097^{\star \star \star}(0.016)$ & $-0.002(0.002)$ & $-0.099^{\star \star \star}(0.016)$ & 0.92 \\
\hline Developing Asia & $0.030^{* * \star}(0.003)$ & $-0.010^{* \star *}(0.003)$ & $0.020^{* * *}(0.004)$ & $0.015^{\star \star \star}(0.003)$ & $-0.010^{* * *}(0.002)$ & $0.005^{\star \star}(0.002)$ & 0.91 \\
\hline Viet Nam & $0.061^{\star \star \star}(0.006)$ & $-0.004(0.003)$ & $0.057^{\star \star \star}(0.007)$ & $0.028^{\star \star \star}(0.004)$ & $-0.006^{\star * \star}(0.002)$ & $0.022^{\star \star \star}(0.004)$ & 0.91 \\
\hline Sri Lanka & $0.054^{\star \star *}(0.006)$ & $-0.005(0.003)$ & $0.049^{* \star *}(0.006)$ & $0.039^{\star * *}(0.006)$ & $-0.007^{* * *}(0.002)$ & $0.033^{* * \star}(0.006)$ & 0.91 \\
\hline Cambodia & $0.049 * \star \star(0.007)$ & $-0.004(0.003)$ & $0.045^{\star \star \star}(0.007)$ & $0.031^{\star \star \star}(0.003)$ & $-0.006^{\star \star \star}(0.002)$ & $0.025^{\star \star \star}(0.003)$ & 0.91 \\
\hline Thailand & $0.044^{\star \star \star}(0.006)$ & $-0.005(0.003)$ & $0.040^{\star \star \star}(0.006)$ & $0.025^{\star \star \star}(0.004)$ & $-0.006^{\star \star \star}(0.002)$ & $0.019^{\star \star \star}(0.004)$ & 0.91 \\
\hline Indonesia & $0.026^{\star \star \star}(0.005)$ & $-0.003(0.003)$ & $0.023^{\star \star \star}(0.006)$ & $0.010^{\star \star}(0.004)$ & $-0.005^{\star \star \star}(0.002)$ & $0.004(0.004)$ & 0.91 \\
\hline China & $0.016^{\star \star}(0.006)$ & $-0.003(0.003)$ & $0.013^{*}(0.007)$ & $-0.025^{\star \star \star}(0.007)$ & $-0.005^{\star \star *}(0.002)$ & $-0.029^{* * *}(0.007)$ & 0.91 \\
\hline Nepal & $0.015^{\star \star \star}(0.004)$ & $-0.003(0.003)$ & $0.012^{\star \star \star}(0.004)$ & $0.023^{\star \star \star}(0.003)$ & $-0.006^{\star \star \star}(0.002)$ & $0.017^{\star \star \star}(0.003)$ & 0.91 \\
\hline Bangladesh & $0.013(0.011)$ & $-0.003(0.003)$ & $0.010(0.011)$ & $-0.016^{*}(0.009)$ & $-0.005^{\star \star \star}(0.002)$ & $-0.021^{\star \star}(0.009)$ & 0.91 \\
\hline Laos & $0.007(0.004)$ & $-0.003(0.003)$ & $0.004(0.005)$ & $0.012^{\star \star *}(0.003)$ & $-0.005^{\star \star \star}(0.002)$ & $0.006 *(0.003)$ & 0.91 \\
\hline Pakistan & $-0.003(0.006)$ & $-0.003(0.003)$ & $-0.006(0.007)$ & $-0.006(0.005)$ & $-0.005^{\star \star \star}(0.002)$ & $-0.011^{\star \star}(0.005)$ & 0.91 \\
\hline Myanmar & $-0.004(0.004)$ & $-0.003(0.003)$ & $-0.007(0.005)$ & $-0.004(0.003)$ & $-0.005^{\star \star \star}(0.002)$ & $-0.009^{\star \star \star}(0.003)$ & 0.91 \\
\hline Malaysia & $-0.005(0.010)$ & $-0.003(0.003)$ & $-0.007(0.010)$ & $0.013(0.011)$ & $-0.006^{\star \star \star}(0.002)$ & $0.008(0.011)$ & 0.91 \\
\hline India & $-0.008^{\star}(0.004)$ & $-0.003(0.003)$ & $-0.011 *(0.006)$ & $-0.004(0.003)$ & $-0.005^{\star \star \star}(0.002)$ & $-0.010^{\star \star *}(0.003)$ & 0.91 \\
\hline Philippines & $-0.024^{\star \star \star}(0.003)$ & $-0.002(0.003)$ & $-0.027^{\star * *}(0.004)$ & $-0.011^{\star * *}(0.003)$ & $-0.005^{\star \star \star}(0.002)$ & $-0.016^{\star \star \star}(0.003)$ & 0.91 \\
\hline Latin America & $-0.013^{* * *}(0.003)$ & $0.001(0.003)$ & $-0.012^{\star * *}(0.003)$ & $-0.008^{\star * *}(0.002)$ & $-0.003(0.002)$ & $-0.012^{* * *}(0.002)$ & 0.91 \\
\hline Bolivia & $0.032^{\star \star \star}(0.004)$ & $-0.004(0.003)$ & $0.028^{\star * \star}(0.004)$ & $0.029^{\star * \star}(0.004)$ & $-0.006^{\star \star \star}(0.002)$ & $0.023^{\star \star \star}(0.004)$ & 0.91 \\
\hline Ecuador & $0.006^{\star \star}(0.003)$ & $-0.003(0.003)$ & $0.003(0.003)$ & $0.003(0.002)$ & $-0.005^{\star \star \star}(0.002)$ & $-0.003(0.002)$ & 0.91 \\
\hline Brazil & $0.004(0.004)$ & $-0.003(0.003)$ & $0.002(0.005)$ & $0.005(0.004)$ & $-0.005^{\star \star \star}(0.002)$ & $-0.001(0.004)$ & 0.91 \\
\hline Colombia & $-0.001(0.004)$ & $-0.003(0.003)$ & $-0.003(0.004)$ & $-0.004(0.004)$ & $-0.005^{\star \star \star}(0.002)$ & $-0.009 * \star(0.004)$ & 0.91 \\
\hline Mexico & $-0.017^{\star \star \star}(0.004)$ & $-0.002(0.003)$ & $-0.019 * * \star(0.004)$ & $-0.006(0.005)$ & $-0.005^{\star \star \star}(0.002)$ & $-0.011^{\star *}(0.005)$ & 0.91 \\
\hline Argentina & $-0.018^{\star \star \star}(0.005)$ & $-0.002(0.003)$ & $-0.020^{\star \star *}(0.005)$ & $-0.023^{\star \star \star}(0.005)$ & $-0.005^{\star *}(0.002)$ & $-0.028^{\star * \star}(0.005)$ & 0.91 \\
\hline Chile & $-0.023^{\star \star \star}(0.003)$ & $-0.002(0.003)$ & $-0.025^{\star \star \star}(0.004)$ & $-0.016^{\star \star \star}(0.003)$ & $-0.005^{\star \star \star}(0.002)$ & $-0.021^{\star \star *}(0.002)$ & 0.91 \\
\hline Peru & $-0.026^{\star \star \star}(0.003)$ & $-0.002(0.003)$ & $-0.028^{\star \star \star}(0.004)$ & $-0.021^{\star \star \star}(0.004)$ & $-0.005^{\star \star \star}(0.002)$ & $-0.025^{\star \star \star}(0.004)$ & 0.91 \\
\hline
\end{tabular}




\begin{tabular}{|c|c|c|c|c|c|c|c|}
\hline Countries by region & $2010 \mathrm{~s} \times \mathrm{C}$ & 2010s & $\begin{array}{l}\text { Marginal effect } \\
\text { (net shift) }\end{array}$ & $2000 \mathrm{~s} \times \mathrm{C}$ & $2000 \mathrm{~s}$ & $\begin{array}{l}\text { Marginal effect } \\
\text { (net shift) }\end{array}$ & $\mathbf{R}^{2}$ \\
\hline Costa Rica & $-0.053^{\star \star \star}(0.005)$ & $-0.002(0.003)$ & $-0.055^{\star \star \star}(0.005)$ & $-0.028^{\star \star \star}(0.004)$ & $-0.005^{\star \star \star}(0.002)$ & $-0.032^{\star \star \star}(0.004)$ & 0.91 \\
\hline Middle East and North & $0.005(0.003)$ & $-0.003(0.003)$ & $0.002(0.004)$ & $0.012^{\star \star \star}(0.003)$ & $-0.006^{\star * \star}(0.002)$ & $0.006^{* *}(0.003)$ & 0.91 \\
\hline Turkey & $0.035^{\star \star \star}(0.005)$ & $-0.003(0.003)$ & $0.032^{\star \star \star}(0.006)$ & $0.041^{\star \star \star}(0.005)$ & $-0.006^{\star \star \star}(0.002)$ & $0.035^{\star \star \star}(0.005)$ & 0.91 \\
\hline Tunisia & $0.008^{\star \star \star}(0.002)$ & $-0.003(0.003)$ & $0.005^{*}(0.003)$ & $0.012^{\star \star \star}(0.002)$ & $-0.005^{\star \star \star}(0.002)$ & $0.007^{\star \star \star}(0.002)$ & 0.91 \\
\hline Egypt & $0.002(0.003)$ & $-0.003(0.003)$ & $-0.000(0.005)$ & $0.004(0.003)$ & $-0.005^{\star \star \star}(0.002)$ & $-0.002(0.003)$ & 0.91 \\
\hline Morocco & $-0.027^{\star \star \star}(0.002)$ & $-0.002(0.003)$ & $-0.028^{\star \star \star}(0.003)$ & $-0.011^{\star \star \star}(0.002)$ & $-0.005^{\star \star \star}(0.002)$ & $-0.016^{\star \star \star}(0.002)$ & 0.91 \\
\hline Sub-Saharan Africa & $-0.000(0.004)$ & $-0.003(0.003)$ & $-0.003(0.004)$ & $0.003(0.003)$ & $-0.006^{* \star *}(0.002)$ & $-0.003(0.003)$ & 0.91 \\
\hline Senegal & $0.065^{\star \star \star}(0.004)$ & $-0.004(0.003)$ & $0.060^{\star \star \star}(0.005)$ & $0.032^{\star \star \star}(0.004)$ & $-0.006^{\star \star \star}(0.002)$ & $0.026^{\star \star \star}(0.004)$ & 0.91 \\
\hline Burkina Faso & $0.060^{\star \star \star}(0.009)$ & $-0.004(0.003)$ & $0.056^{\star \star \star}(0.010)$ & $0.009^{\star \star \star}(0.003)$ & $-0.005^{\star \star \star}(0.002)$ & $0.004(0.003)$ & 0.91 \\
\hline Lesotho & $0.057^{\star \star \star}(0.005)$ & $-0.008^{\star \star}(0.003)$ & $0.050^{\star \star \star}(0.005)$ & $0.056^{\star \star \star}(0.006)$ & $-0.008^{\star \star \star}(0.002)$ & $0.048^{\star \star \star}(0.006)$ & 0.91 \\
\hline Kenya & $0.042^{\star \star \star}(0.005)$ & $-0.003(0.003)$ & $0.039^{\star \star \star}(0.006)$ & $0.042^{\star \star \star}(0.005)$ & $-0.006^{\star \star \star}(0.002)$ & $0.036^{\star \star \star}(0.005)$ & 0.91 \\
\hline Cameroon & $0.024^{\star \star \star}(0.003)$ & $-0.003(0.003)$ & $0.022^{\star \star \star}(0.005)$ & $0.007^{\star \star \star}(0.002)$ & $-0.005^{\star \star \star}(0.002)$ & $0.001(0.003)$ & 0.91 \\
\hline Mozambique & $0.022^{\star \star \star}(0.006)$ & $-0.004(0.003)$ & $0.018^{\star \star \star}(0.006)$ & $0.025^{\star \star \star}(0.004)$ & $-0.006^{\star \star \star}(0.002)$ & $0.019 \star \star \star ~(0.004)$ & 0.91 \\
\hline Namibia & $0.012^{\star \star}(0.005)$ & $-0.003(0.003)$ & $0.009 *(0.005)$ & $0.008^{\star \star \star}(0.003)$ & $-0.005^{\star \star \star}(0.002)$ & $0.002(0.003)$ & 0.91 \\
\hline Ethiopia & $0.012^{\star \star \star}(0.004)$ & $-0.003(0.003)$ & $0.009(0.006)$ & $0.016^{\star \star \star}(0.003)$ & $-0.005^{\star \star \star}(0.002)$ & $0.010^{\star \star \star}(0.003)$ & 0.91 \\
\hline Botswana & $0.011^{* \star}(0.005)$ & $-0.002(0.003)$ & $0.008(0.006)$ & $0.011^{\star \star}(0.004)$ & $-0.005^{\star \star \star}(0.002)$ & $0.005(0.004)$ & 0.91 \\
\hline Malawi & $0.004(0.004)$ & $-0.003(0.003)$ & $0.001(0.005)$ & $0.006^{\star}(0.003)$ & $-0.005^{\star \star \star}(0.002)$ & $0.001(0.003)$ & 0.91 \\
\hline South Africa & $-0.001(0.004)$ & $-0.003(0.003)$ & $-0.004(0.004)$ & $0.021^{\star \star \star}(0.003)$ & $-0.006^{\star \star \star}(0.002)$ & $0.015^{\star \star \star}(0.003)$ & 0.91 \\
\hline Rwanda & $-0.005(0.005)$ & $-0.003(0.003)$ & $-0.007(0.005)$ & $0.001(0.004)$ & $-0.005^{\star \star \star}(0.002)$ & $-0.004(0.004)$ & 0.91 \\
\hline Ghana & $-0.006(0.007)$ & $-0.002(0.003)$ & $-0.009(0.008)$ & $-0.016^{\star \star \star}(0.004)$ & $-0.005^{\star \star \star}(0.002)$ & $-0.021^{\star \star \star}(0.004)$ & 0.91 \\
\hline Zambia & $-0.042^{\star \star \star}(0.005)$ & $-0.003(0.003)$ & $-0.045^{\star \star \star}(0.006)$ & $-0.033^{\star \star \star}(0.005)$ & $-0.005^{\star \star \star}(0.002)$ & $-0.039^{\star \star \star}(0.005)$ & 0.91 \\
\hline Tanzania & $-0.043^{\star \star \star}(0.004)$ & $-0.003(0.003)$ & $-0.046^{\star \star \star}(0.006)$ & $-0.024^{\star \star \star}(0.004)$ & $-0.005^{\star \star \star}(0.002)$ & $-0.029^{\star \star \star}(0.004)$ & 0.91 \\
\hline Uganda & $-0.056^{\star \star \star}(0.003)$ & $-0.003(0.003)$ & $-0.058^{\star \star \star}(0.005)$ & $-0.025^{\star \star \star}(0.005)$ & $-0.005^{\star \star \star}(0.002)$ & $-0.031^{* * \star}(0.005)$ & 0.91 \\
\hline Nigeria & $-0.059^{\star \star \star}(0.010)$ & $-0.004(0.003)$ & $-0.063^{\star \star \star}(0.011)$ & $-0.056^{\star \star \star}(0.010)$ & $-0.005^{\star \star \star}(0.002)$ & $-0.061^{\star \star \star}(0.010)$ & 0.91 \\
\hline Mauritius & $-0.098^{\star \star \star}(0.004)$ & $0.002(0.003)$ & $-0.096^{\star \star \star}(0.004)$ & $-0.038^{\star \star \star}(0.009)$ & $-0.003^{*}(0.002)$ & $-0.041^{\star * \star}(0.009)$ & 0.91 \\
\hline $\begin{array}{l}\text { Sub-Saharan Africa } \\
\text { excl. Mauritius }\end{array}$ & $0.013^{\star \star *}(0.004)$ & $-0.006^{*}(0.003)$ & $0.007^{*}(0.004)$ & $0.009^{\star \star \star}(0.003)$ & $-0.007^{\star * \star}(0.002)$ & $0.002(0.002)$ & 0.91 \\
\hline
\end{tabular}

Note: dependent variable is the manufacturing employment share. Regressions estimated using equation (2). Each row represents a regression with period interactions with the respective country relative to the 50 other ETD countries. Countries within each region ordered by direction and magnitude of deviation. Coefficients for control variables omitted for brevity. Results for each country-specific regression are available upon request. Robust standard errors in parentheses. Delta-method Taylor approximations for standard errors of net effects. * $p<0.10,{ }^{\star \star} p<0.05,{ }^{\star \star \star} p<0.01$.

Source: authors' construction. 
Table B3: Regional and country-specific industrialization trends, manufacturing value added share in constant prices

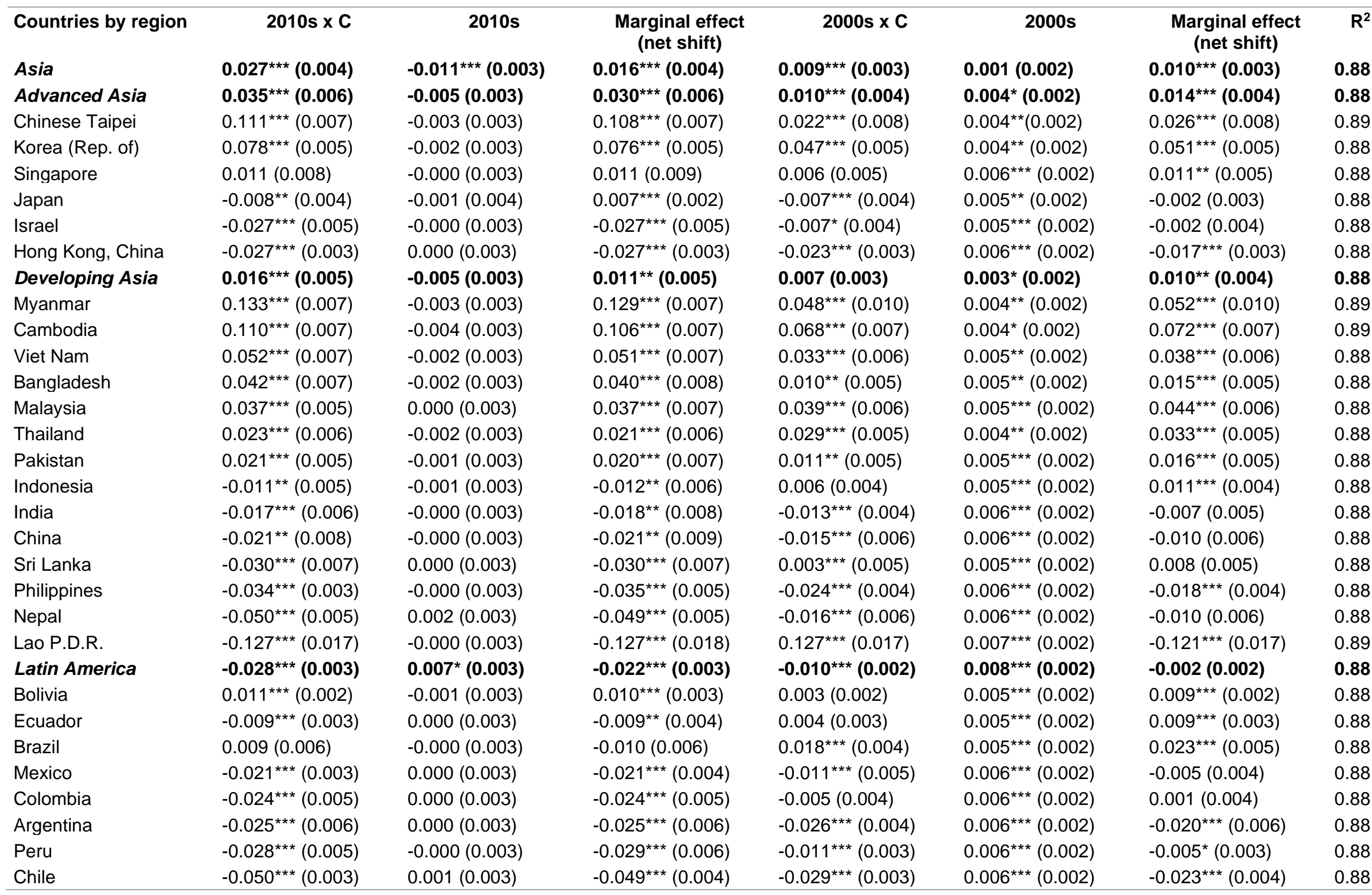




\begin{tabular}{|c|c|c|c|c|c|c|c|}
\hline Countries by region & $2010 s \times C$ & 2010s & $\begin{array}{l}\text { Marginal effect } \\
\text { (net shift) }\end{array}$ & $2000 s \times C$ & $2000 s$ & $\begin{array}{l}\text { Marginal effect } \\
\text { (net shift) }\end{array}$ & $\mathbf{R}^{2}$ \\
\hline Costa Rica & $-0.052^{\star \star \star}(0.004)$ & $0.000(0.003)$ & $-0.051^{\star \star \star}(0.004)$ & $-0.019 * \star \star(0.005)$ & $0.006^{\star \star \star}(0.002)$ & $-0.013^{\star \star \star}(0.005)$ & 0.88 \\
\hline Middle East and North & $-0.001(0.004)$ & $-0.001(0.003)$ & $-0.002(0.005)$ & $0.003(0.004)$ & $0.005^{\star \star *}(0.002)$ & $0.008^{*}(0.004)$ & 0.88 \\
\hline Turkey & $0.021^{\star \star \star}(0.004)$ & $-0.001(0.003)$ & $0.020 * \star \star(0.005)$ & $0.003(0.004)$ & $0.005^{\star \star \star}(0.002)$ & $0.008^{\star \star}(0.005)$ & 0.88 \\
\hline Egypt & $0.016^{\star \star \star}(0.005)$ & $-0.000(0.003)$ & $0.015^{\star \star}(0.007)$ & $0.031^{\star \star \star}(0.007)$ & $0.005^{\star \star}(0.002)$ & $0.036^{\star \star \star}(0.007)$ & 0.88 \\
\hline Tunisia & $-0.020 \star \star \star ~(0.006)$ & $0.000(0.003)$ & $-0.020 \star \star \star ~(0.006)$ & $-0.001(0.006)$ & $0.005^{\star \star \star}(0.002)$ & $0.005(0.006)$ & 0.88 \\
\hline Morocco & $-0.021^{\star \star *}(0.004)$ & $0.000(0.003)$ & $-0.021^{\star * *}(0.005)$ & $-0.023^{\star \star \star}(0.005)$ & $0.006^{\star \star \star}(0.002)$ & $-0.017^{\star \star \star}(0.005)$ & 0.88 \\
\hline Sub-Saharan Africa & $-0.007(0.005)$ & $0.001(0.004)$ & $-0.006(0.005)$ & $0.002(0.004)$ & $0.006^{* *}(0.002)$ & $0.004(0.003)$ & 0.88 \\
\hline Mozambique & $0.055^{\star \star \star}(0.008)$ & $-0.003(0.003)$ & $0.051^{\star \star \star}(0.008)$ & $0.066^{\star \star \star}(0.007)$ & $0.004^{\star}(0.002)$ & $0.069^{\star \star \star}(0.007)$ & 0.88 \\
\hline Cameroon & $0.047^{\star \star \star}(0.004)$ & $-0.001(0.003)$ & $0.046^{\star \star \star}(0.005)$ & $0.017^{\star \star \star}(0.006)$ & $0.005^{\star \star \star}(0.002)$ & $0.022^{\star \star \star}(0.006)$ & 0.88 \\
\hline Malawi & $0.041^{\star * \star}(0.004)$ & $-0.001(0.003)$ & $0.040 * \star *(0.005)$ & $-0.003(0.003)$ & $0.006^{\star \star \star}(0.002)$ & $0.002(0.005)$ & 0.88 \\
\hline Burkina Faso & $0.024^{\star * \star}(0.006)$ & $-0.001(0.003)$ & $0.023^{\star \star \star}(0.007)$ & 0.020 *** $(0.006)$ & $0.005^{\star \star \star}(0.002)$ & $0.025^{\star \star \star}(0.006)$ & 0.88 \\
\hline Tanzania & $0.017^{\star \star \star}(0.005)$ & $-0.001(0.003)$ & $0.017^{\star \star}(0.007)$ & $0.001(0.003)$ & $0.006^{\star \star \star}(0.002)$ & $0.007^{*}(0.004)$ & 0.88 \\
\hline Uganda & $0.018 * \star(0.007)$ & $-0.001(0.003)$ & $0.017^{\star \star}(0.008)$ & $0.019^{\star \star \star}(0.007)$ & $0.005^{\star \star \star}(0.002)$ & $0.025^{\star \star \star}(0.007)$ & 0.88 \\
\hline Botswana & $0.016 * * \star(0.006)$ & $-0.001(0.003)$ & $0.016^{\star \star}(0.007)$ & $-0.005(0.005)$ & $0.006^{\star \star \star}(0.002)$ & $0.001(0.005)$ & 0.88 \\
\hline Lesotho & $0.018 * \star(0.008)$ & $-0.002(0.003)$ & $0.015^{\star \star}(0.007)$ & $0.078^{\star \star \star}(0.011)$ & $0.003(0.002)$ & $0.081^{\star \star \star}(0.011)$ & 0.88 \\
\hline Ethiopia & $0.013^{\star \star}(0.005)$ & $-0.001(0.003)$ & $0.012^{\star}(0.006)$ & $0.003(0.003)$ & $0.005^{\star \star \star}(0.002)$ & $0.008^{\star \star}(0.003)$ & 0.88 \\
\hline Namibia & $0.012^{\star}(0.006)$ & $-0.001(0.003)$ & $0.011^{*}(0.006)$ & $0.010^{\star *}(0.005)$ & $0.005^{\star \star \star}(0.002)$ & $0.015^{\star \star \star}(0.004)$ & 0.88 \\
\hline Senegal & $-0.004(0.004)$ & $-0.001(0.003)$ & $-0.004(0.005)$ & $-0.004(0.004)$ & $0.005^{\star \star \star}(0.002)$ & $0.002(0.005)$ & 0.88 \\
\hline Zambia & $-0.008(0.006)$ & $-0.001(0.003)$ & $-0.009(0.007)$ & $-0.006(0.004)$ & $0.005^{\star \star \star}(0.002)$ & $-0.001(0.004)$ & 0.88 \\
\hline Kenya & $-0.013^{\star \star \star}(0.004)$ & $-0.001(0.003)$ & $-0.013^{\star \star}(0.005)$ & $-0.010^{* * *}(0.003)$ & $0.005^{\star \star \star}(0.002)$ & $-0.005^{\star}(0.003)$ & 0.88 \\
\hline Rwanda & $-0.016^{\star \star \star}(0.005)$ & $-0.000(0.003)$ & $-0.016^{\star \star \star}(0.006)$ & $-0.019^{\star \star \star}(0.004)$ & $0.006^{\star \star \star}(0.002)$ & $-0.013^{\star \star \star}(0.004)$ & 0.88 \\
\hline South Africa & $-0.030^{\star \star \star}(0.003)$ & $-0.000(0.003)$ & $-0.030^{* \star *}(0.004)$ & $-0.017^{\star \star \star}(0.003)$ & $0.006^{\star \star \star}(0.002)$ & $-0.011^{\star \star \star}(0.003)$ & 0.88 \\
\hline Ghana & $-0.046^{\star \star \star}(0.007)$ & $-0.000(0.003)$ & $-0.046^{\star \star \star}(0.008)$ & $-0.018^{\star \star \star}(0.004)$ & $0.005^{\star \star \star}(0.002)$ & $-0.012^{\star \star \star}(0.004)$ & 0.88 \\
\hline Mauritius & $-0.075^{\star \star \star}(0.005)$ & $0.003(0.003)$ & $-0.071^{\star \star \star}(0.005)$ & $-0.044^{\star \star \star}(0.007)$ & $0.007^{\star \star \star}(0.002)$ & $-0.036^{\star \star \star}(0.006)$ & 0.88 \\
\hline Nigeria & $-0.116^{\star \star \star}(0.012)$ & $-0.004(0.003)$ & $-0.119 * \star *(0.013)$ & $-0.095^{\star \star \star}(0.015)$ & $0.005^{\star \star}(0.002)$ & $-0.090 * \star \star(0.010)$ & 0.89 \\
\hline $\begin{array}{l}\text { Sub-Saharan Africa } \\
\text { excl. Mauritius }\end{array}$ & $0.003(0.005)$ & $-0.001(0.004)$ & $0.002(0.005)$ & $0.003(0.004)$ & $0.004^{*}(0.002)$ & $0.008^{\star \star}(0.003)$ & 0.88 \\
\hline
\end{tabular}

Note: dependent variable is the real manufacturing value added share. Regressions estimated using equation (2). Each row represents a regression with period interactions with the respective country relative to the 50 other ETD countries. Countries within each region ordered by direction and magnitude of deviation. Coefficients for control variables omitted for brevity. Results for each country-specific regression are available upon request. Robust standard errors in parentheses. Delta-method Taylor approximations for standard errors of net effects. ${ }^{*} p<0.10,{ }^{* \star} p<0.05,{ }^{* \star *} p<0.01$.

Source: authors' construction. 
Table B4: Regressions, manufacturing employment share by 2-digit industry, sub-Saharan Africa

\begin{tabular}{|c|c|c|c|c|c|c|c|c|c|}
\hline & Food & Text & $\begin{array}{l}\text { Wood, paper } \\
\text { \& print }\end{array}$ & $\begin{array}{c}\text { Petro, chemicals } \\
\text { \& rubber }\end{array}$ & $\begin{array}{l}\text { Minerals \& } \\
\text { metals }\end{array}$ & $\begin{array}{l}\text { Computer } \\
\text { \& electrical }\end{array}$ & Machinery & Transport & Furni; oth. \\
\hline \multirow[t]{2}{*}{ Ln population } & $-0.060^{\star \star \star}$ & -0.039 & 0.006 & $0.091^{\star \star *}$ & $0.039 * \star \star$ & $0.047^{\star * *}$ & -0.001 & $0.016^{\star \star}$ & 0.002 \\
\hline & $(0.012)$ & $(0.050)$ & $(0.007)$ & $(0.021)$ & $(0.011)$ & $(0.008)$ & $(0.002)$ & $(0.007)$ & $(0.004)$ \\
\hline \multirow{2}{*}{$\begin{array}{l}\text { Ln population } \\
\text { squared }\end{array}$} & $0.002^{\star \star \star}$ & 0.002 & -0.000 & $-0.003^{\star \star \star}$ & $-0.001^{\star \star \star}$ & $-0.001^{\star \star \star}$ & 0.000 & $-0.000 * \star$ & -0.000 \\
\hline & $(0.000)$ & $(0.002)$ & $(0.000)$ & $(0.001)$ & $(0.000)$ & $(0.000)$ & $(0.000)$ & $(0.000)$ & $(0.000)$ \\
\hline \multirow[t]{2}{*}{ Ln GDP per capita } & $0.020 * \star \star$ & $0.123^{\star \star \star}$ & $0.014^{\star \star *}$ & 0.008 & $0.022^{\star \star \star}$ & 0.024 *** & $-0.004^{\star * *}$ & 0.004 & $0.009^{* \star *}$ \\
\hline & $(0.005)$ & $(0.025)$ & $(0.002)$ & $(0.007)$ & $(0.006)$ & $(0.003)$ & $(0.001)$ & $(0.003)$ & $(0.002)$ \\
\hline \multirow{2}{*}{$\begin{array}{l}\text { Ln GDP per capita } \\
\text { squared }\end{array}$} & $-0.001^{* \star *}$ & $-0.008^{\star * *}$ & $-0.001^{\star \star *}$ & -0.000 & $-0.001^{* * *}$ & $-0.002^{\star * *}$ & $0.000 * * *$ & -0.000 & $-0.001^{* \star *}$ \\
\hline & $(0.000)$ & $(0.002)$ & $(0.000)$ & $(0.000)$ & $(0.000)$ & $(0.000)$ & $(0.000)$ & $(0.000)$ & $(0.000)$ \\
\hline \multirow[t]{2}{*}{$2000 s$} & $-0.001 * *$ & $-0.010^{\star * *}$ & $-0.000^{* *}$ & $0.001^{*}$ & $-0.001^{* *}$ & -0.000 & 0.000 & $-0.000^{* *}$ & $-0.000^{* \star *}$ \\
\hline & $(0.000)$ & $(0.003)$ & $(0.000)$ & $(0.000)$ & $(0.000)$ & $(0.000)$ & $(0.000)$ & $(0.000)$ & (0.000) \\
\hline \multirow[t]{2}{*}{ 2010s } & $-0.002^{\star \star}$ & $-0.022^{\star \star \star}$ & $-0.001^{\star \star \star}$ & 0.000 & $-0.001^{\star \star \star}$ & -0.000 & 0.000 & $-0.001^{\star *}$ & $-0.001^{\star \star *}$ \\
\hline & $(0.001)$ & (0.005) & $(0.000)$ & (0.001) & $(0.000)$ & $(0.000)$ & $(0.000)$ & $(0.000)$ & $(0.000)$ \\
\hline Observations & 370 & 370 & 341 & 232 & 329 & 175 & 336 & 169 & 370 \\
\hline $\mathrm{R}^{2}$ & 0.947 & 0.902 & 0.947 & 0.923 & 0.936 & 0.970 & 0.975 & 0.959 & 0.955 \\
\hline
\end{tabular}

Notes: dependent variable is the manufacturing employment share. Regressions are estimated using (1). Robust standard errors in parentheses. ${ }^{*} p<0.10,{ }^{\star \star} p<0.05$, *** $p<0.01$

Source: authors' construction. 